\title{
Urban Shrinkage in Eastern Germany
}

\author{
Florian W. Bartholomae \\ Chang Woon Nam \\ Alina M. Schoenberg
}

\author{
CESIFO WORKING PAPER NO. 5200 \\ CATEgory 6: Fiscal Policy, Macroeconomics and Growth \\ FEBRUARY 2015
}
An electronic version of the paper may be downloaded
- from the SSRN website: Www.SSRN.com
- from the RePEc website: $\quad$ www.RePEc.org
- from the CESifo website: www.CESifo-group.org/wp




\title{
Urban Shrinkage in Eastern Germany
}

\begin{abstract}
This paper questions the widely applied parallelism of demographic and economic development in characterizing urban shrinkage in Germany, and argues that the usage of population change as a single indicator leads to incorrect policy recommendations for combating urban shrinkage. As the cases of several Ruhr cities (Essen, Gelsenkirchen and Dortmund) and East German cities (Erfurt, Rostock and Magdeburg) prove, urban economic growth can also be achieved thanks to the substantial presence of modern industries and business services, and despite declines in population size. The serious shrinkage of Halle, Cottbus and Schwerin is primarily due to failures in the post-industrial transformation process. Recent policy measures strongly oriented towards slowing the downsizing process of population (via urban regeneration measures to hinder suburbanisation and low core urban density) do not address this major problem effectively. More active industrial policy measures are required in these East German shrinking cities to create a competitive manufacturing sector (endowed with new high-tech firms) and to boost its growth interdependence with modern local services.
\end{abstract}

JEL-Code: P250, O140, O380, R110, H760.

Keywords: urban shrinkage, East Germany, post-industrial transformation, parallelism of demographic and economic development, smart growth, modern industries and services.

Florian W. Bartholomae

Bundeswehr University of Munich

Werner-Heisenberg-Weg 39

Germany - 85577 Neubiberg

florian.bartholomae@unibw.de
Chang Woon Nam

Ifo Institute - Leibniz Institute for

Economic Research

at the University of Munich

Poschingerstrasse 5

Germany - 81679 Munich

nam@ifo.de

Alina M. Schoenberg

Bundeswehr University of Munich

Werner-Heisenberg-Weg 39

Germany-85577 Neubiberg

alina.schoenberg@unibw.de 


\section{Introduction}

The world is continuing to experience a trend towards urbanisation. According to UN (2014), 54\% of the world population is presently living in urban areas, and this share is expected to grow to $66 \%$ by 2050. In Europe, the figure totalled 73\% in 2014. Despite this trend, a large number of cities have been suffering from economic declines and population losses, and at the same time, have undergone economic transformation with some symptoms of a structural crisis (see also Oswalt, 2006). According to Hollander et al. (2009), one in six cities worldwide was shrinking even before the US subprime mortgage crisis in 2007, while approximately one-third of all European cities with 200,000+ inhabitants experienced at least a ten-year population decline at least once between 1960 and 2005 (see also Turok and Mykhnrnko, 2007). The failure to achieve a timely and smooth post-industrial shift from traditional manufacturing to more sophisticated, innovation-driven high-tech industries and modern business-oriented services, which was also triggered by the relocation and polarisation of economic activities in a global context, has not only caused serious unemployment and outmigration problems in many urban areas, but has also contributed to the gradual, worldwide rise in the number of shrinking cites (Cunningham-Sabot and Fol, 2009; Bartholomae and Nam, 2014a).

Other determinants leading to urban shrinkage include suburbanisation, ${ }^{1}$ war, natural or man-made disasters, an ageing or low-fertility rate population, etc. (see also Bontje and Musterd (2012) and Lin (2014)). All these changes have not only weakened the economic power of urban areas, but have also deteriorated the fiscal base of cities, which, in turn, has created financial bottlenecks in maintaining local infrastructure levels, as well as quality of life. As a result, the challenges related to vacant and underutilised housing, uncompetitive, old local business firms, as well as a poor communication and transportation system and other infrastructure like schools, waste

1 Thanks to improvements in transport and communication systems, industry, commerce, residences and government offices have increasingly moved to, or newly located outside of the city centre (see also Audirac, 2014). Furthermore, the continuing trend towards lower density urban areas, "is the result of increasing household affluence, which led to increased personal mobility and permitted housing to be larger and often on larger plots of land. In addition, over the period, average household sizes were reduced substantially, which also contributed to population decline [in the cities]" (Cox, 2014, p. 23). 
disposal facilities, etc. have rapidly emerged (see also Hollander et al., 2009; Bartholomae and Nam, 2014b). ${ }^{2}$

It is generally said that the East German urban shrinkage caused by economic and structural transformation, which took place immediately after the 1990 unification, has been most pronounced and serious in Europe. However, the recent economic and demographic development has been quite different from one East German city to another (Hannemann, 2003; Franz, 2004; Mulder, 2009; Steinführer and Haase, 2007; Gatzweiler and Milbert, 2009; Rink et al., 2010; Bartholomae and Nam, 2014a). For example, Dresden and Leipzig have been better able to overcome the difficulties, while some middle-sized cities such as Jena and Rostock, offering attractive jobs, historical centres and high-quality education facilities, have also been acknowledged to be quite successful (see also Hospers, 2014).

In fact, the comparable post-industrial transformations had started in Germany in the 1970s which have been the major causes for the shrinkage of several urban cores in the old industrial regions of its western part. These Ruhr cities with their traditional coal mining and steel industry had to carry out massive and painful structural reforms in order to enhance their competitiveness (Wiegandt, 2000; Gatzweiler et al., 2003; Nipper, Schulz and Wiratanaya, 2009; Leadbeater, 2009), while Bremen’s decline was primarily led by the collapse of the dominant shipbuilding sector (see also Göschel,

2 Martinez-Fernandez et al. (2012) and Morrill (2014) assess the urban shrinkage as "a multidimensional complex of demographic (e.g. aging and population loss), socio-economic (e.g. economic downturn, employment decline, and poverty [and crime] concentration), [...] and physical processes and effects (e.g. infrastructure, housing or industrial deterioration and abandonment) in constant interaction and as unmistakable symptoms of a structural crisis at work" (Audirac, 2014, p. 28). According to Richardson and Nam (2014), there is no single theory of urban shrinkage existing at present. Nevertheless a number of 'urban decline' factors can be identified from several existing development theories. Neo-classical growth theories postulate that economic decline occurs, for example, either if one major production factor (such as labour, capital and technical progress) fails to expand or if the endowment of all these factors becomes scarce, due to wars, natural disasters, etc. New growth theory implicitly argues that the acceleration of urban decline emerges, if factors shaping infrastructure-related increasing returns to scale, synergy and learning effects in the local production process are neglected. According to Malthus (1798), the mismatch between the increase in production output and population size occurring beyond equilibrium can lead to economic decline. Moreover, especially in urban areas, economic sustainability can only be guaranteed, when industrial production process is accompanied by the preservation of environmental basis, otherwise decline follows (Pike et al., 2007). A less-competitive educational system and improper knowledge transfers (combined with brain drain) not only imped the formation of urban human capital but also slow down its transformation process from traditional agricultural to modern industrial and service society. Based on the principal logic of central places theory highlighting that the role of such central places diminishes as the delivery distances get larger and/or as transport costs continue to increase, the urban shrinkage is attributed to the reduction of agglomeration advantages (e.g. central location with special infrastructure, specific labour and entrepreneurship experiences, better access to innovations and the synergy effects created by industrial clusters, etc.). Economic decline can also emerge when there are serious government failures, corruption and political instability (Szirmai, 2005). 
2003; Bartholomae and Nam, 2014a). Even by the end of 1980s most large West German shrinking cities were found in the northern part of Germany, whereas Munich, Frankfurt and Stuttgart in the South have been growing fast (Friedrichs et al., 1986; Dormhardt and Troeger-Weiß, 2009). But, although their population size is diminishing, these Ruhr cities have recently demonstrated that urban economic revival and smart growth is possible, if there is a gradual shift in the sectoral structure from old manufacturing to more sophisticated high-tech industries, as well as modern services, since the latter are generally acknowledged to have a stronger urban orientation (see also Kermer, 2007). This has undoubtedly has been a long, uneasy development process that should continue in the future. Furthermore, the number of single adult households and the DINKS ('double income, no kids': i.e. couples in work with no children) has also been increasing. Such 'modern' demographic trends and new life styles favouring city locations, coupled with their demand for attractive urban amenities, have reduced further suburbanisation (see also Cheshire and Hay, 1989; Cox, 2014).

This paper primarily deals with important issues related to urban shrinkage in eastern Germany. The first question addressed is related to the widely assumed parallelism of demographic and economic development in characterising urban shrinkage in Germany. In this context we argue that using population change as the only indicator of urban growth and decline tends to lead to incorrect policy recommendations and measures to combat urban shrinkage. As seen in several Ruhr and East German large cities, urban economic growth can also be achieved despite population declines (socalled 'smart' or 'lean' growth), in cases where the large-scale presence of modern industries and business services guarantees urban economic recovery. Urban shrinkage in eastern Germany is frequently caused by a post-industrial transformation failure and, for this reason, today's marked policy orientation towards slowing the downsizing process of population (via 'cosmetic' urban regeneration measures aimed at hindering suburbanisation and low core urban density) does not tackle the root of the problem, but merely addresses its symptoms. More 'proactive' industrial (structural) policy measures are urgently required in eastern Germany's shrinking cities to create a competitive manufacturing sector (endowed with new high-tech firms) and to foster growth interdependence with modern local services. 


\section{Identification of Urban Shrinkage in Germany: Economic vs. De- mographic Perspective}

Among regional scientists, population change is the most widely used indicator to identify urban growth and decline (Rink et al., 2012; Hospers, 2014) since "[first] population change is an important consequence of urban conditions. [Similar to Tiebout (1956)] migration [can also be seen as] a response to differences in employment or the quality of life between [cities, which, in turn, leads to fierce competition among them]. Secondly, population change also exerts an important influence over urban economic conditions [because] sheer population size and deep labour pools increase agglomeration economies and productivity in terms of better realising both economies of scale and scope. Population downturns have certainly caused wider economic, financial and environmental problems for cities and their authorities, while shifts in population size affect local jobs through demand for consumer goods and [public] services, housing, schools, etc. Changes in working age residents also affect the supply of skills, which may influence mobile investment decisions” (Turok and Mykhnenko, 2007, p. 167).

However, population change alone does not fully capture the economic development of a city. For example, Franz (2004) highlights the existence of a rather loose relationship between demographic and economic development: with high unemployment rates a reduction in the 'natural' labour supply caused by the extra population decline will hardly limit the growth of a city, as the idle working population continues to remain huge in this urban area. Furthermore, 'jobless' urban growth, which is more or less independent of the labour supply development in the same area, can also be achieved if the city can sharply increase its productivity (see also Ragnitz et al., 2001; Berlemann and Wesselhöft, 2012; Bartholomae and Nam, 2014a).

Urban productivity can be enhanced in various ways: via massive investment in human capital and R\&D infrastructure; a proactive location policy (including the establishment of technology parks) aimed at attracting high-tech industries and modern services combined with the 'brain gain'; support for the establishment of local innovation networks and the creation of modern industrial and service clusters, ideally linked with their national and international counterparts, etc. All of these factors contribute to the better realisation of agglomeration advantages (Glaeser et al., 1992; Mills and McDonalds, 1992; Nam et al., 2005; Friedrich and Nam, 2013). In particular, the discussion of a productivity gap among eastern German cities has recently gained prominence in the rather vivid concept of a 'lean city', as well as ‘smart urban growth' debates (see also 
Fuhrich, 2003; Lang and Tenz, 2003), since Germany expects a continuous decline in population size in the long-run -a fact that could further worsen demographic problems in already shrinking cities (Bartholomae and Nam, 2014a). ${ }^{3}$

Figures 1 to 3 depict the differences in population change and real GVA development of selected large German cities in the period of 1995-2007. Without neglecting the idea of the parallelism of demographic development and economic change, but also with adequate consideration given to its methodological disputes mentioned above, four varied categories of urban development can be identified via simple comparisons of these two indicators, ${ }^{4}$ as shown in Table 1:

- Category 1: Shrinking cities suffering from demographic and economic decline at the same time,

- Category 2: Smartly growing cities experiencing demographic decline, but enjoying favourable economic growth,

- Category 3: Unproductive growing cities achieving expansion of population size, but suffering from economic decline, and

- Category 4: Growing cities experiencing both demographic and economic growth (see also Bartholomae and Nam, 2014a).

To verify whether cities are still suffering from the post-industrial transformation process that started in 1970s, three groups of large cities were selected for the investigation: firstly the traditional, large West German cities such as Hamburg, Bremen, Düsseldorf, Cologne, Frankfurt, Stuttgart and Munich; and secondly some Ruhr cities including Bochum, Dortmund, Essen und Gelsenkirchen. The third, most important group features eastern German cities that were strongly struck by the post-socialist shock after Germany's reunification in 1990, namely Berlin, Cottbus, Dresden, Erfurt, Halle (an der Saale), Jena, Leipzig, Magdeburg, Rostock, Schwerin and Weimar. Are all of these cities still experiencing the economic and demographic shrinkage that was generally observed at the beginning of the 1990s? Are there any sign of reversal in these eastern German cities?

\footnotetext{
According to the official national forecast until 2025, the population size of East German cities is expected to decline by up to 25\% (see also Statistisches Bundesamt, 2000; Krautzberger, 2001; Domhardt and Troeger-Weiß, 2009; Schlömer, 2009).

4 Together with the population data, the urban gross value added (GVA) data expressed in real terms are adopted for this simple analysis for the period between 1995 and 2007. Both sets of data are gathered and updated, as well as regularly revised by the German statistical office. The time horizon for the statistical comparison is limited to 2007, since the on-going economic crisis in Europe has heavily (and to differing degrees) impacted the economic performances of German cities in the following years.
} 
Figure 1: Demographic and Real GVA Changes in Large West German Cities (19952007)

a. Demographic Change $(1995=100)$

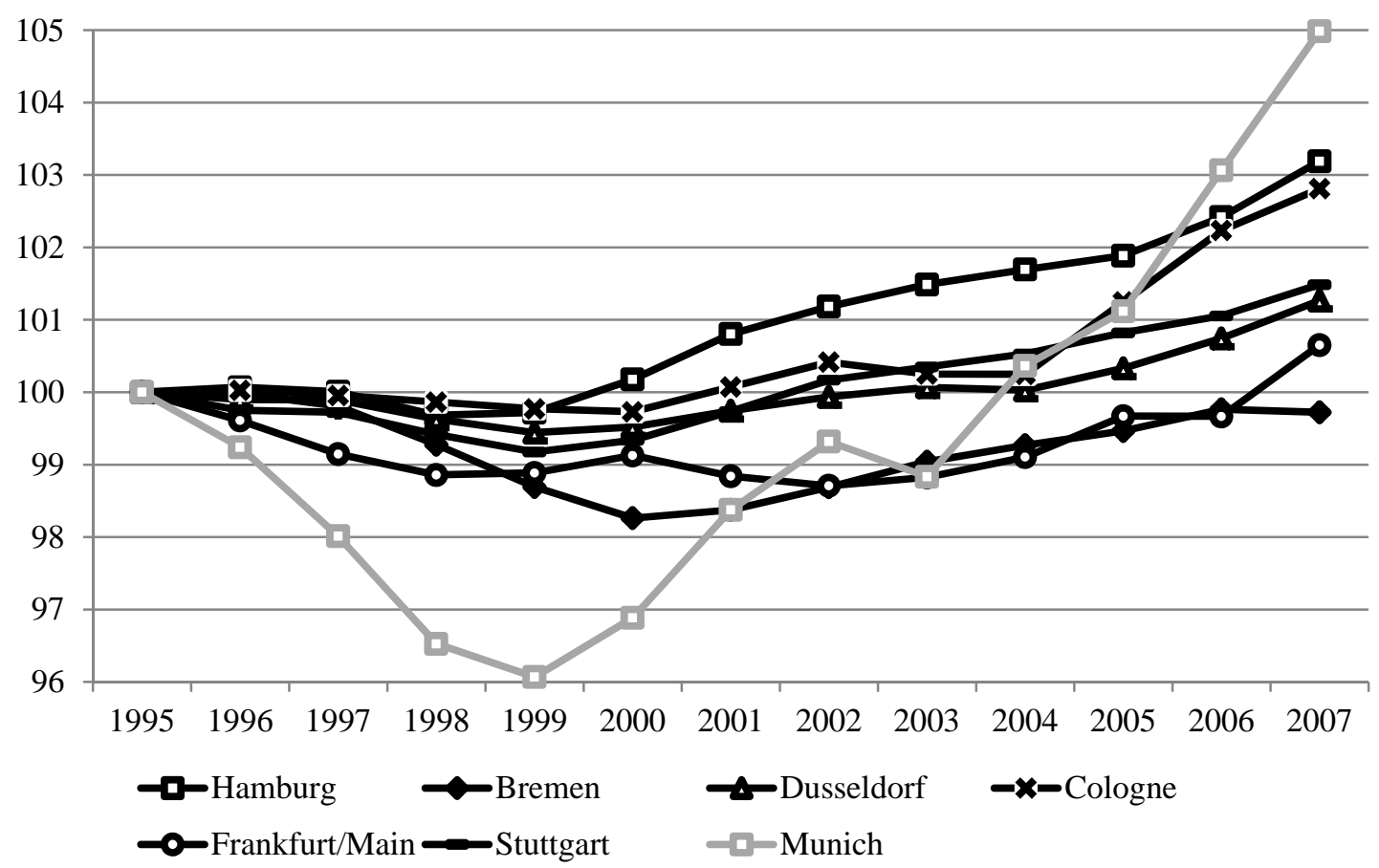

Source: Table A2 in annex

b. Real GVA Change $(1995=100)$

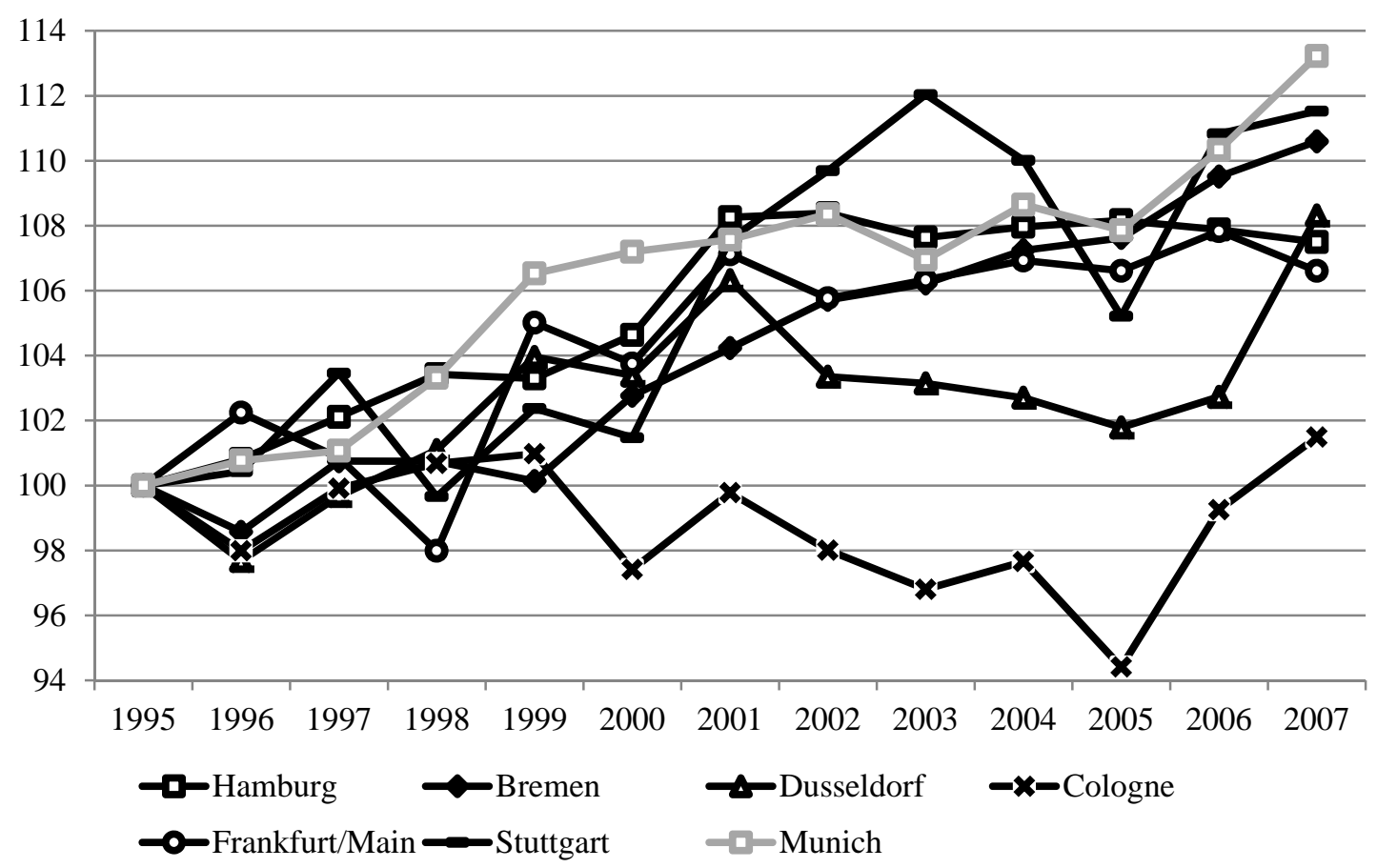

Source: Table A1 in annex 
Figure 2: Demographic and Real GVA Changes in Selected Ruhr cities (1995-2007)

a. Demographic Change $(1995=100)$

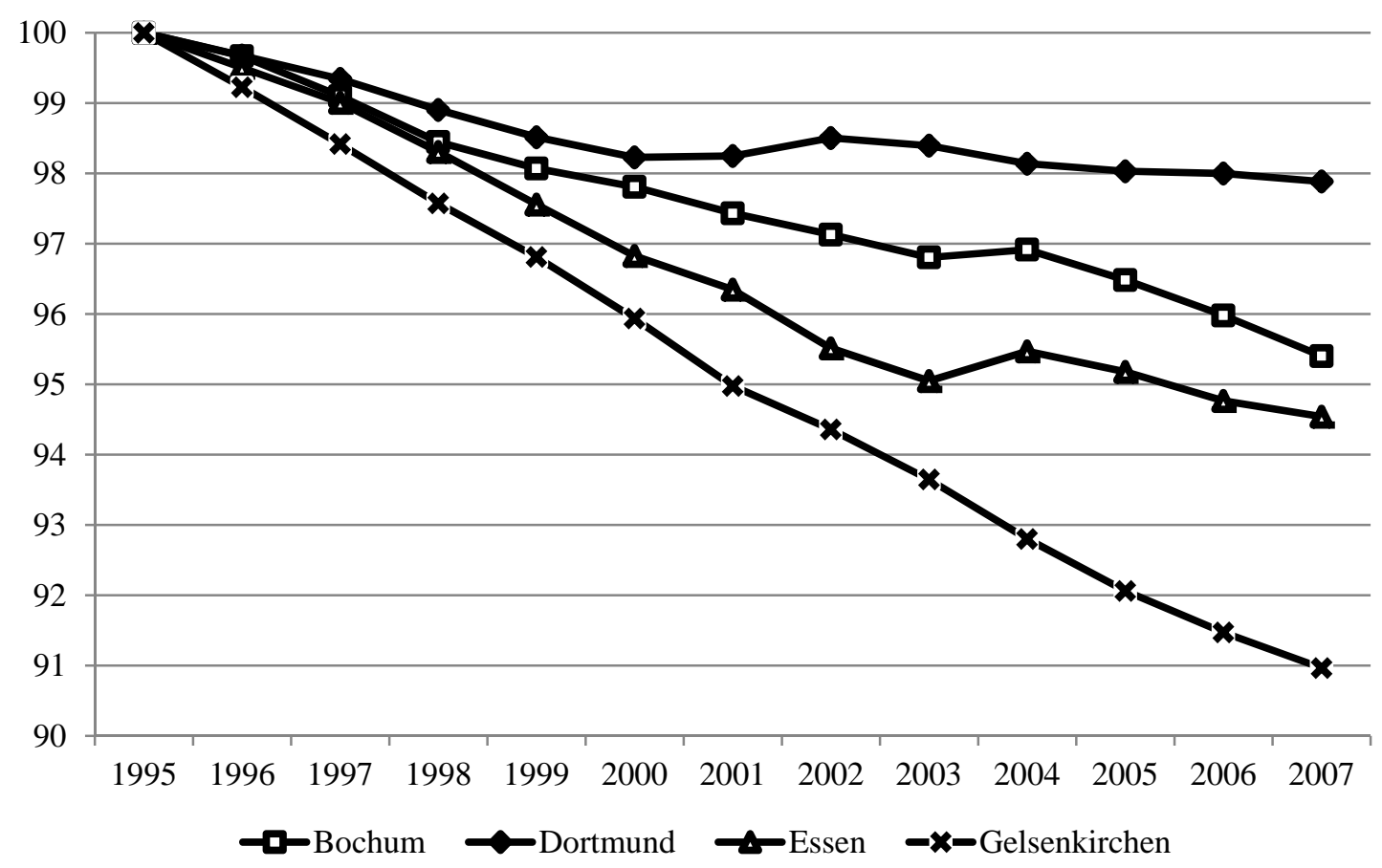

Source: Table A2 in annex

b. Real GVA Change $(1995=100)$

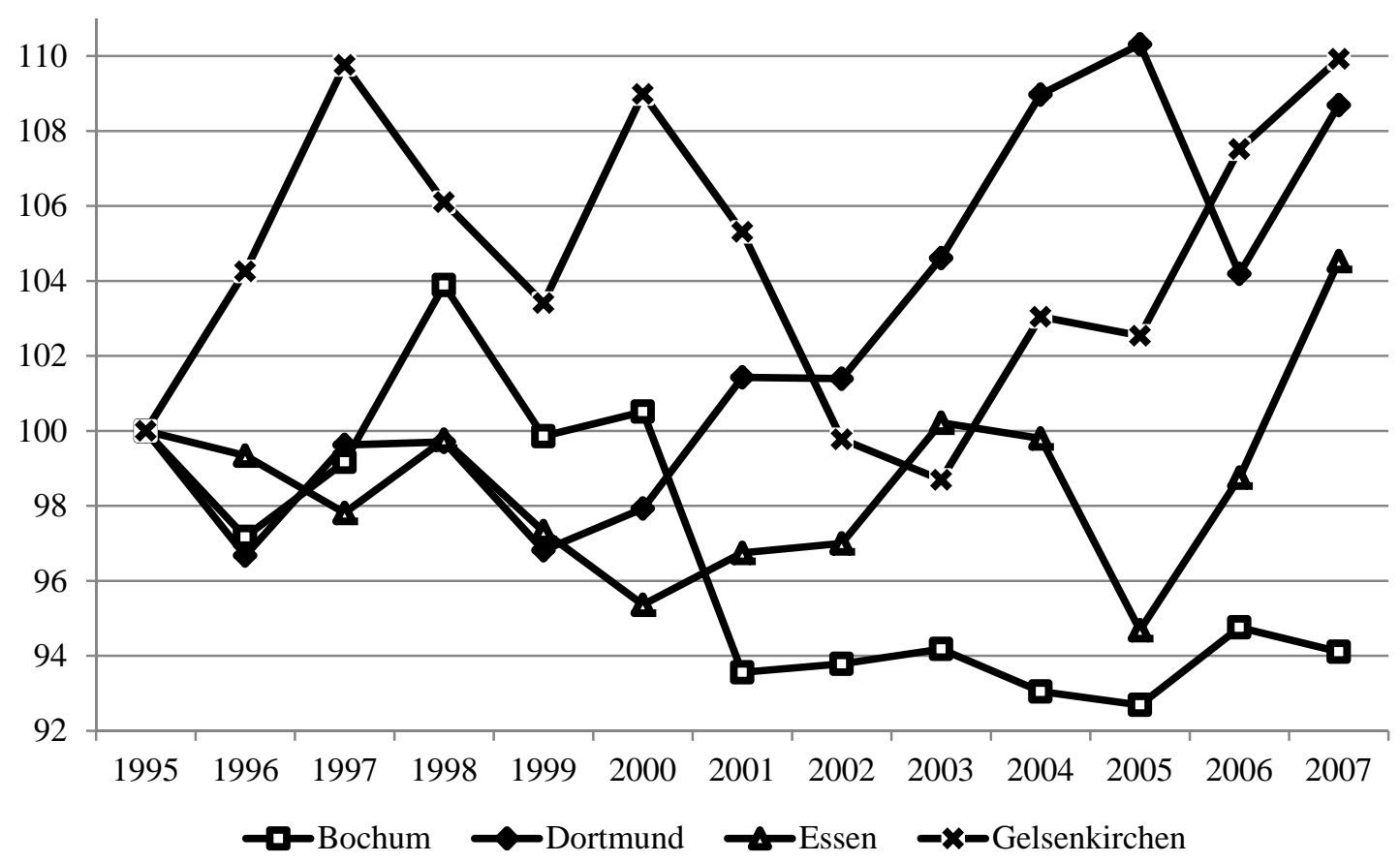

Source: Table A1 in annex 
Figure 3: Demographic and Real GVA Changes in Large East German Cities (19952007)

a. Demographic Change $(1995=100)$

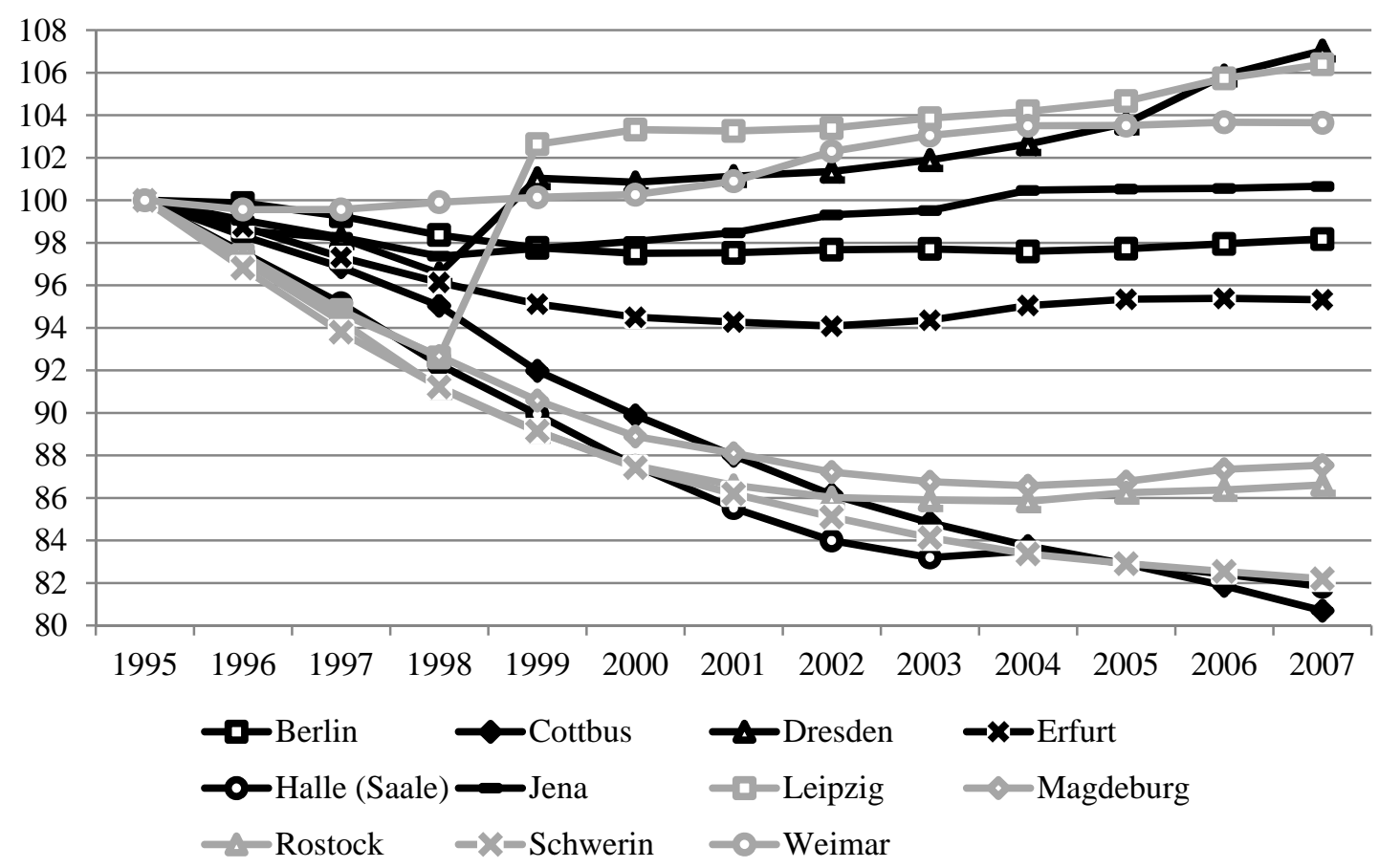

Source: Table A2 in annex

b. Real GVA Change $(1995=100)$

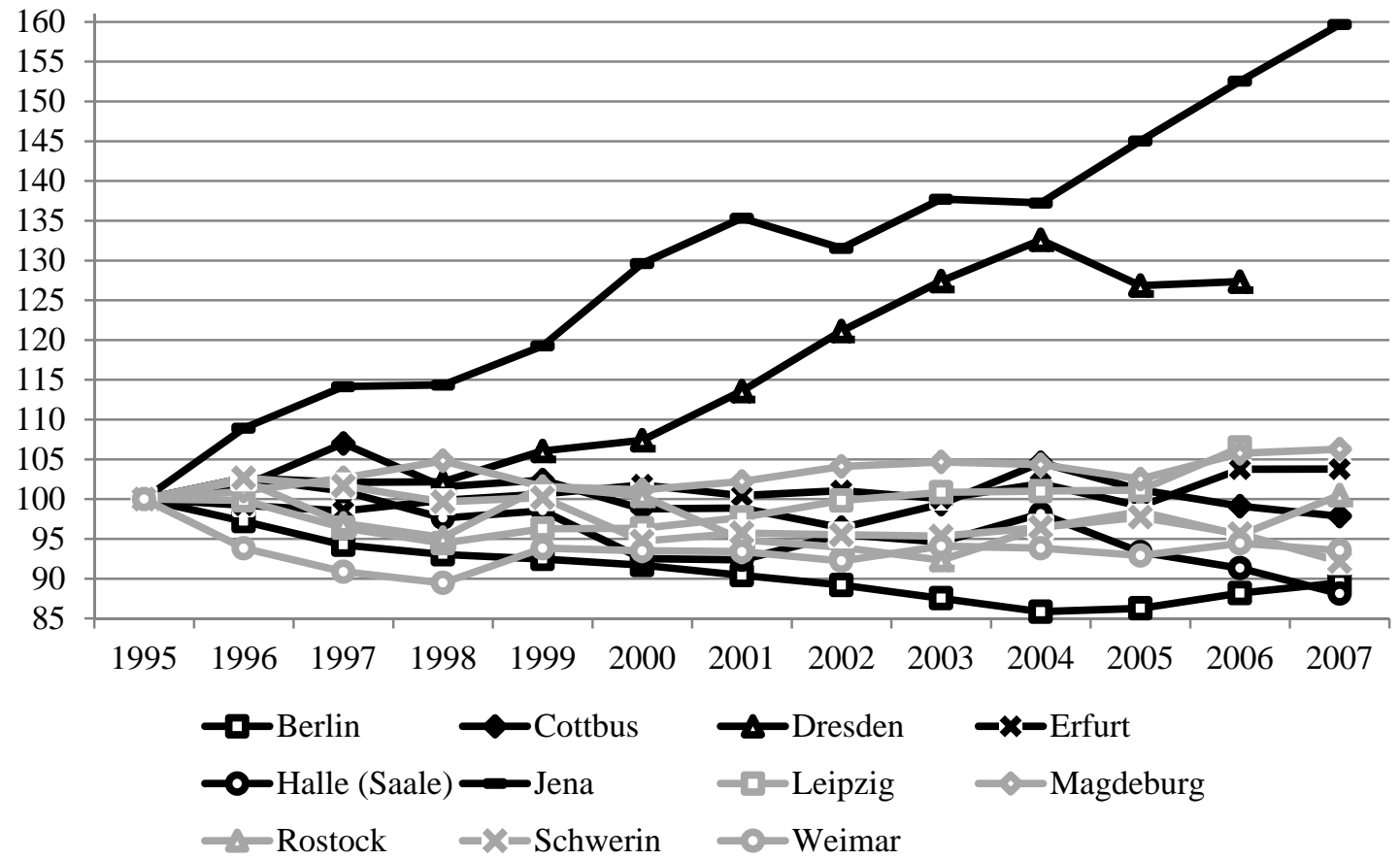

Source: Table A1 in annex 
Table 1: Classification of Selected Large German Cities According to Changes in GVA and Population Size (1995-2007)

\begin{tabular}{lll}
\hline & Demographic decline & Demographic growth \\
\hline $\begin{array}{l}\text { Economic } \\
\text { decline }\end{array}$ & Shrinking Cities & Unproductive Growing Cities \\
& $\begin{array}{l}\text { Bochum** } \\
\text { Berlin, Cottbus, Schwerin \& Halle*** }\end{array}$ & Weimar*** \\
Economic & Smartly Growing Cities & Growing Cities \\
growth & Bremen* & Hamburg, Düsseldorf, Cologne, \\
& Essen, Gelsenkirchen \& Dortmund** & Frankfurt, Stuttgart \& Munich* \\
& Erfurt, Magdeburg \& Rostock*** & Dresden, Leipzig \& Jena*** \\
\hline
\end{tabular}

Note: $\quad *$ Traditional large cities in Western Germany;

** Selected Ruhr cities;

*** Large cities in the eastern part of Germany.

Source: Bartholomae and Nam (2014a); Figures 1 to 3; Tables A1and A2 in annex.

During the period from 1995 to 2007, all the large cities investigated in this paper that are located in the West (Hamburg, Düsseldorf, Cologne, Frankfurt, Stuttgart and Munich, but not Bremen) experienced demographic expansion and economic growth at the same time, while Dresden, Leipzig ${ }^{5}$ and Jena are also considered growing cities. The real GVA growth was most remarkable in Jena (ca. 60\%) and in Dresden (ca. 27\% - see Figure 3b), followed by Munich and Stuttgart (ca. 12 to 13\% - see Figure 1b). Leipzig's real GVA growth was moderate at 7\% (Figure 3b). Dresden and Leipzig achieved the greatest population expansion (at 7\% - see Figure 3a). Unlike the favourable demographic development in Munich (5\%), Hamburg and Cologne (3\%), growth in Düsseldorf, Stuttgart and Frankfurt (as well as Jena) remained fairly limited (around 1\% - see also Figure 1a).

Bremen and most of the Ruhr cities investigated show a homogeneous development pattern: during the period of 1995-2007 these 'old' post-industrial transformation cities experienced a demographic decline that was combined with economic growth. In particular Gelsenkirchen demonstrated a rapid real GVA increase (of around $+10 \%$ as shown in Figure 2b), although its number of inhabitants declined by $9 \%$ (see Figure 2a). The significant GVA growth in Bremen and Dortmund (ca. 11\% and 8\%, respectively) was also accompanied by a marginal decrease in population size (less than $2 \%$ ). Magdeburg in eastern Germany also belongs to this 'smartly growing' group: the city expe-

5 However, it has to be noted that a major part of Leipzig's population growth was caused by the annexation of surrounding communities. 
rienced a decrease in population of ca. $12 \%$, but achieved around $6 \%$ growth in real GVA (Figures 3a and 3b).

Five of the large German cities analysed can be defined as the 'shrinking cities': namely Bochum, one of the Ruhr cities, together with the post-socialist transformation cities of Berlin, Cottbus, Halle and Schwerin. Unlike other aforementioned Ruhr cities, Bochum failed to create endogenous, real GVA growth (ca. $-6 \%$ as shown in Figure $2 \mathrm{~b}$ ), whereas the city's population also decreased by around 6\% (Figure 2a). Berlin's demographic change of $-2 \%$ may be assessed as less significant, but it experienced a real GVA loss of around $11 \%$ at the same time. With its rate of $-12 \%$, Halle suffered most seriously from the economic loss that emerged in line with the population decrease of $18 \%$. Schwerin's obvious economic decline of approximately $8 \%$ was combined with a large scale population reduction of around 18\%, while Cottbus suffered from a severe population decline of around $20 \%$, accompanied by a rather moderate economic decline of $2 \%$. Weimar is the only city among the twenty large German cities considered in which the real GVA declined by around 6\%, but the population growth rate amounted to 4\% in the years between 1995 and 2007 (see Figures 3a and 3b).

\section{Comparison of Halle's Structural Problems with Other German Cities}

\subsection{Halle's Economy and Demography: Status Quo}

Traditionally, Halle in Saxony-Anhalt was one of the leading East German industrial centres, specialised in salt, gas and energy, brown coal mining, mechanical engineering, and chemical products (Wallosek, 2006; Bartholomae and Nam, 2014b). Reunification in 1990 created an immense post-social competitiveness shock and a process of massive deindustrialisation, from which these old industries in the city suffered seriously. The dominant, big industrial companies located in the city area were dismembered and privatised, leading to massive unemployment, while expansion in the service sector was relatively weak (see also Rink et al., 2010). Just like most large cities in Germany, Halle currently wishes to attract basic and applied research activities for future technologies such as life science, new materials, solar energy, etc. (City of Halle, 2010). Yet this appears to be an extremely challenging task, since fierce urban competition for R\&D and modern industrial activities currently prevails among large German cities. Service firms account for around half of all companies located in Halle: among others, however, less 
productive, traditional public administration bodies, as well as social and health services are major local job-providers (see also Bartholomae and Nam, 2014b).

With approximately 233,000 inhabitants, Halle is presently the fifth largest city in eastern Germany, surpassed only by Berlin, Dresden, Leipzig and Potsdam in terms of population size. The severe deindustrialisation process in Halle has also triggered the migration of young and skilled workforces to western Germany. The city lost 56,000 inhabitants in the period from 1990 to 1999 as a result (= ca. 18\% of its 1990 total population). However, such a 'job-driven' net outflow of people recently declined from around 12,000 in 1990 to an annual average of 2,000 to 4,000 (Rink et al., 2010; Bartholomae and Nam, 2014b).

Moreover, this demographic shrinkage has also been exacerbated by suburbanisation (i.e. Halle lost ca. 37,000 inhabitants to its surroundings in the period from 1994 to 2001) and ongoing ageing problems in the city area (see also Raschke and Schultz, 2006). Compared to Dresden and Leipzig, Halle lacks a productive cohort aged between 20 and 40, whereas it has a larger share of elderly people aged 50+ (Figure 4). The Statistisches Landesamt Sachsen-Anhalt projects that Halle's population will further decline by 10\% (= ca. 23,000 people) between 2008 (with 233,013 inhabitants) and 2025 (with 209,726 inhabitants). ${ }^{6}$

As a result, high rates of housing and office vacancies, as well as infrastructure oversupply, have recently been seen in the centre of Halle (see also Wiechmann, 2009). ${ }^{7}$ In view of this fact, its urban development plan has recently been mainly oriented towards the model of building a compact city with an attractive urban centre as in other East German cities (see the case of Cottbus in Table 3), which, in turn, provides modern infrastructure and guarantees pleasant living and working conditions. More specifically, the city has been strongly attempting to influence or control the provision process of the social infrastructure system (kindergartens, schools, elderly care facilities, etc.) through a combination of administrative and organisational changes, geographic concentration of such facilities accompanied by qualitative improvements in services, etc. (Stadt Halle, 2008). Neglecting the fact that a sort of smart growth is possible (see the experiences of Essen, Gelsenkirchen and Dortmund), Halle's main strategy to combat urban shrinkage and the economic downturn no longer appears to be growth-oriented (i.e. geared

\footnotetext{
See http://www.statistik.sachsen-anhalt.de/bevoelkerung/prognose/index.html.

Such high housing vacancy ratios and the housing market supply surplus in large East German cities at the end of 1990s were also partly fuelled by generous public promotion schemes (such as accelerated depreciation rules). This, in turn, also led to a construction boom in houses and apartments in suburban municipalities too.
} 
towards attracting modern industries and services), but significant policy efforts have been made to rehabilitate the city-centre in order to stop outward migration and maintain population size.

Figure 4: Age Structure of Halle Compared to Dresden and Leipzig (2010)

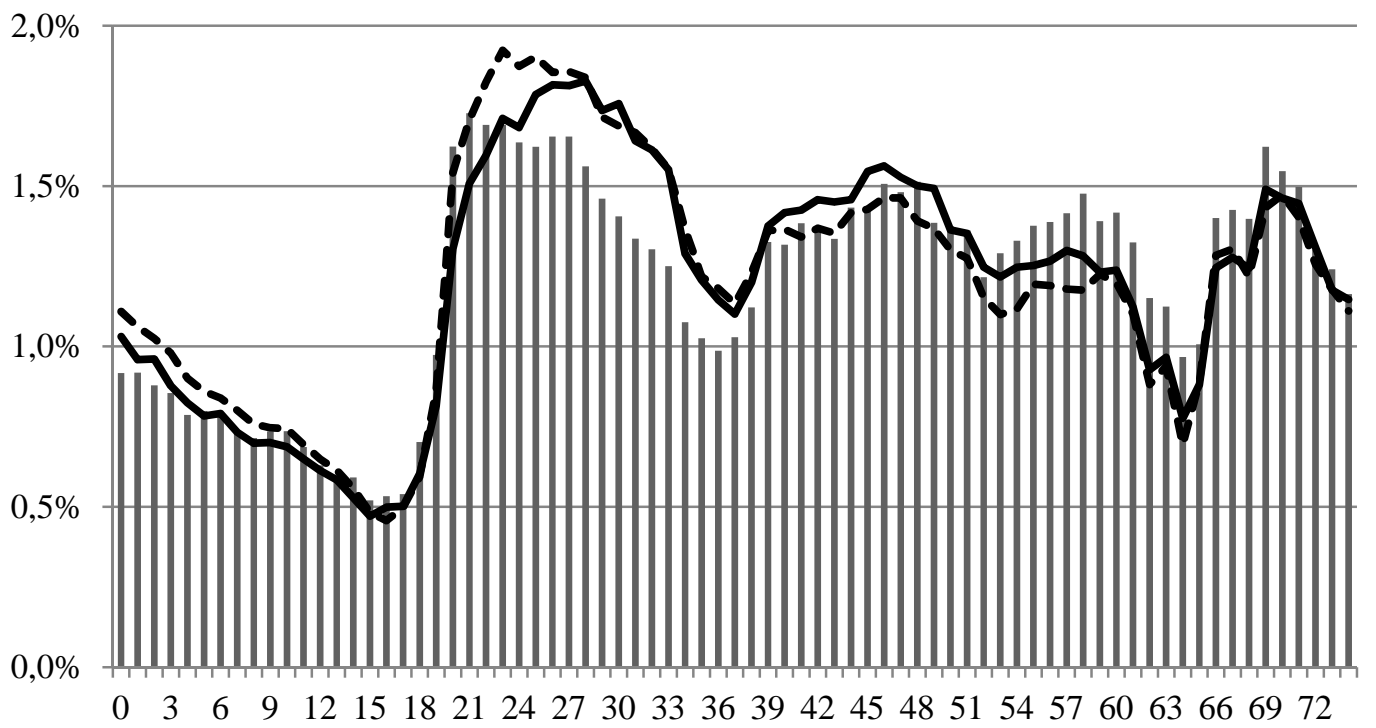

Halle - - Dresden Leipzig

Source: Bartholomae and Nam (2014b); Regional Statistics of Germany; German Federal Statistical Office

\subsection{Comparison of Halle's Economic Structure with Other German Cities}

As already mentioned, Halle's economic and demographic shrinkage is a structural problem. In this context the development and specialisation of various manufacturing sectors combined with the different degree of dominance of individual services delivers crucial information on the key reasons why urban shrinkage continues in a number of eastern German cities, including Halle.

The cobweb diagrams in Figures 5 to 8 compare Halle's employment structure (expressed in terms of the share of employees subject to social insurance contribution) to that of other selected East German cities in 2007. They reveal not only the restructuring and transformation achievement of these cities in the last twenty years, but also their current economic specialisation and competitiveness.

Compared to the two growing cities of Dresden and Jena, Halle's employment share for the 'manufacturing' sector (around 6\%) was significantly low: the corresponding share reached ca. 15\% for Dresden and over 19\% for Jena in 2007 (see Figures 5 
and 7). Moreover, Halle's extremely high employment share for 'education, health, social and other public and personal services' of over 36\% (compared to $26 \%$ and $28 \%$ in Dresden and Leipzig respectively) seriously calls into question whether the city has recently been smoothly transitioning to a modern service society (see Figures 5 and 6, as well as Table A3 in annex). In addition to Halle, Cottbus and Schwerin are also classified as shrinking cities in eastern Germany (see Table 1): Cottbus and Schwerin boast higher employment shares for 'public administration and defense, social insurance', but their general employment structures were very similar to that of Halle in 2007, with a substantial share of employment lacking in manufacturing and modern market services (see Figure 8 and 9).

An analogous comparison of Halle's employment structure with that of the selected 'smartly growing' Ruhr cities reveals a clear difference: Essen, Gelsenkirchen and Dortmund demonstrate an employment structure very similar to that of Dresden. In 2007 all of these growing Ruhr cities and Dresden were equipped with a stronger manufacturing sector combined with a larger share of business and market services than Halle (see Figures 10 to 12). This again implies that urban recovery is not only affected by the performance of an individual city's manufacturing sector, but also that an ideal combination of modern industries and services is a prerequisite for urban growth.

Figure 5: Comparison of Employment Structure between Halle and Dresden (2007)

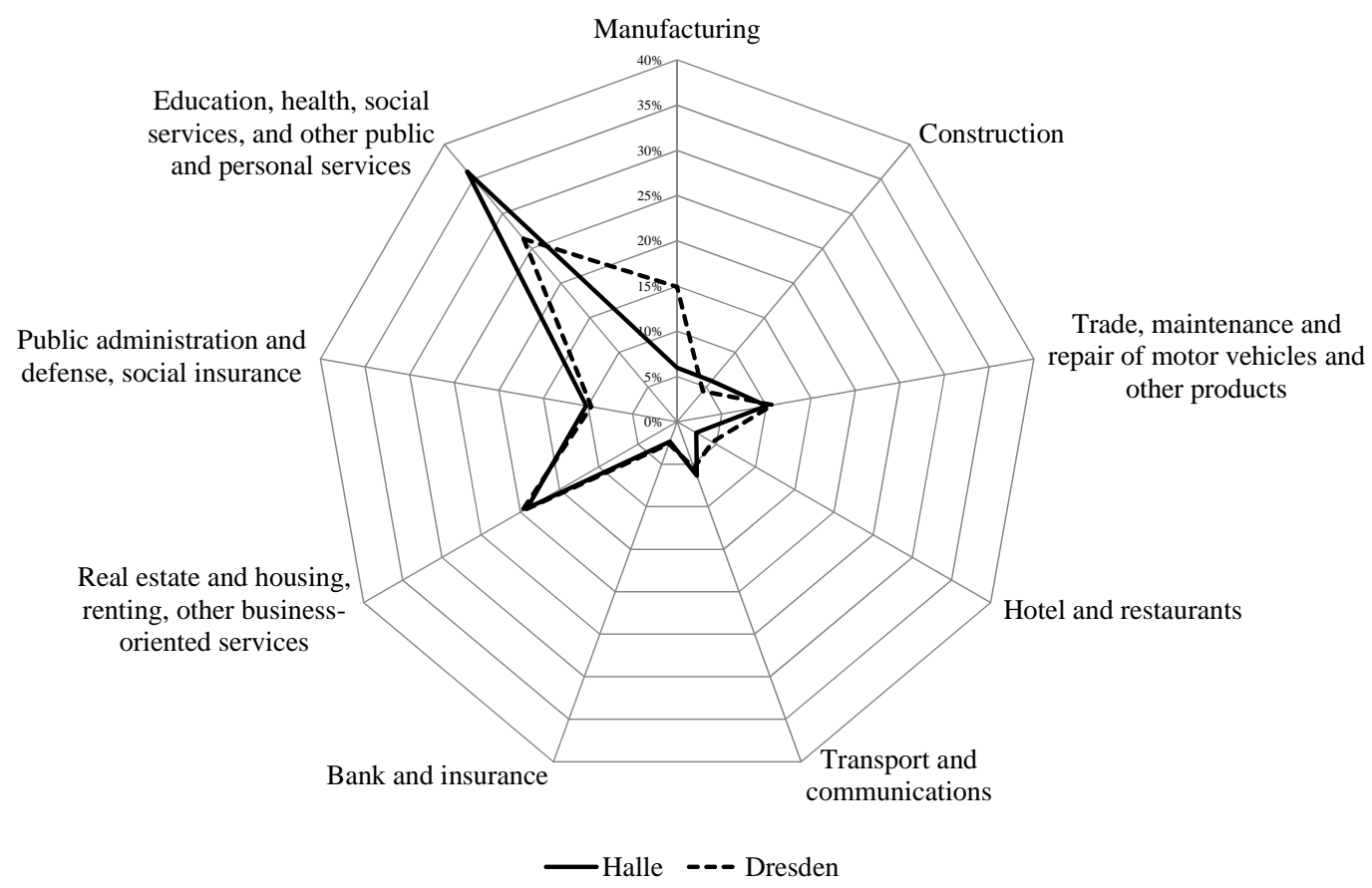

Source: Table A3 in annex. 
Figure 6: Comparison of Employment Structure between Halle and Leipzig (2007)

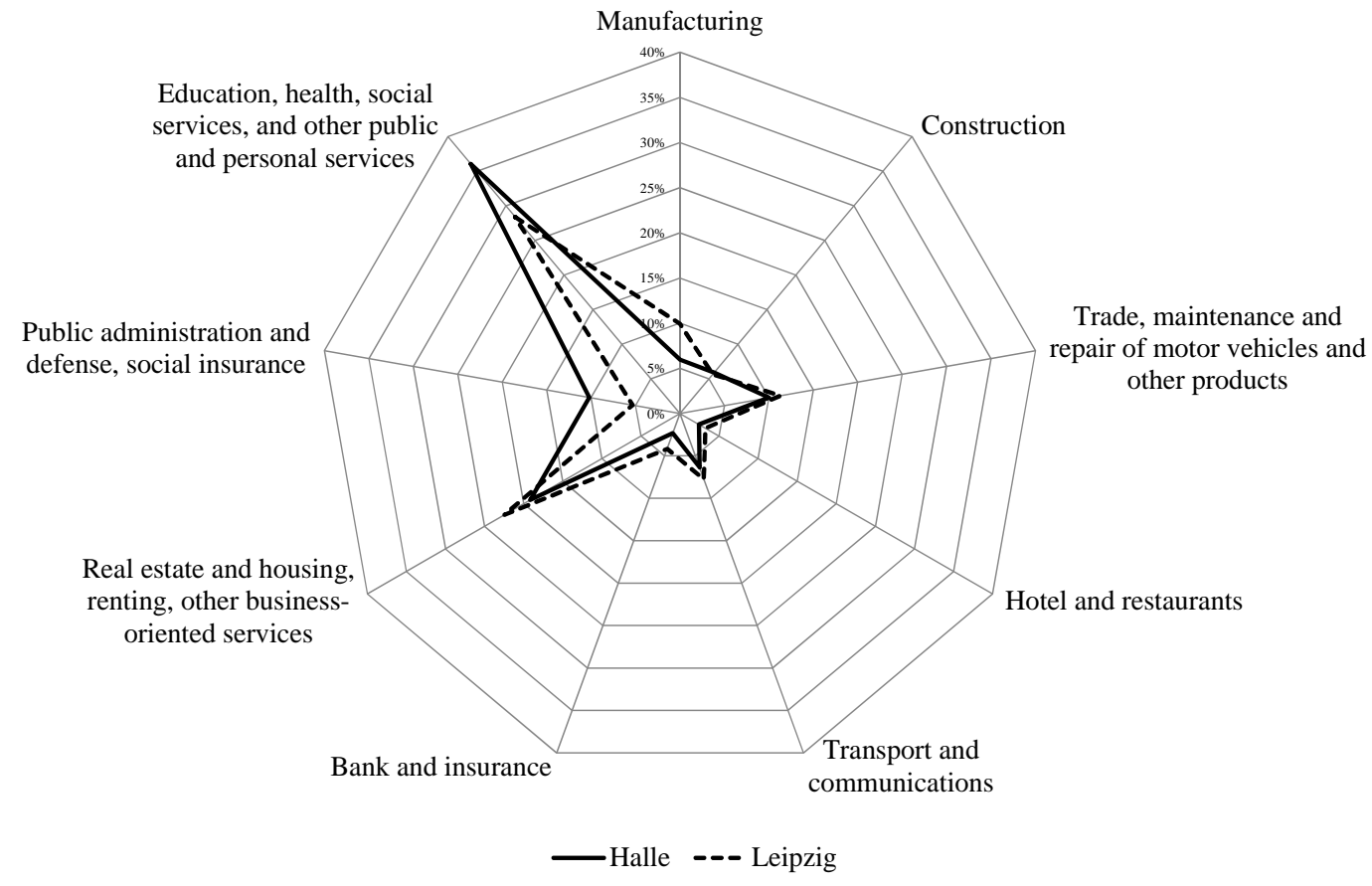

Source: Table A3 in annex.

Figure 7: Comparison of Employment Structure between Halle and Jena (2007)

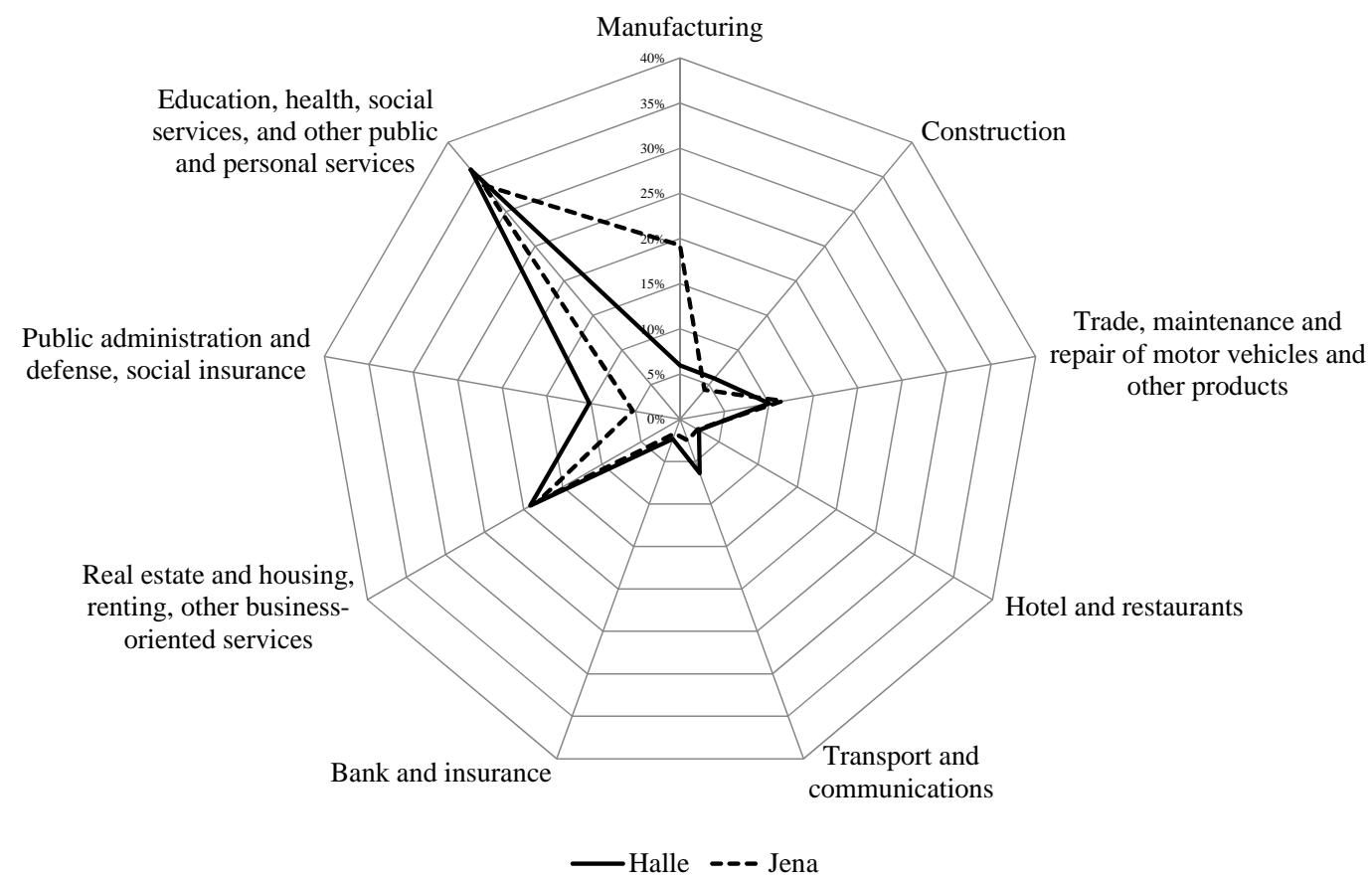

Source: Table A3 in annex. 
Figure 8: Comparison of Employment Structure between Halle and Schwerin (2007)

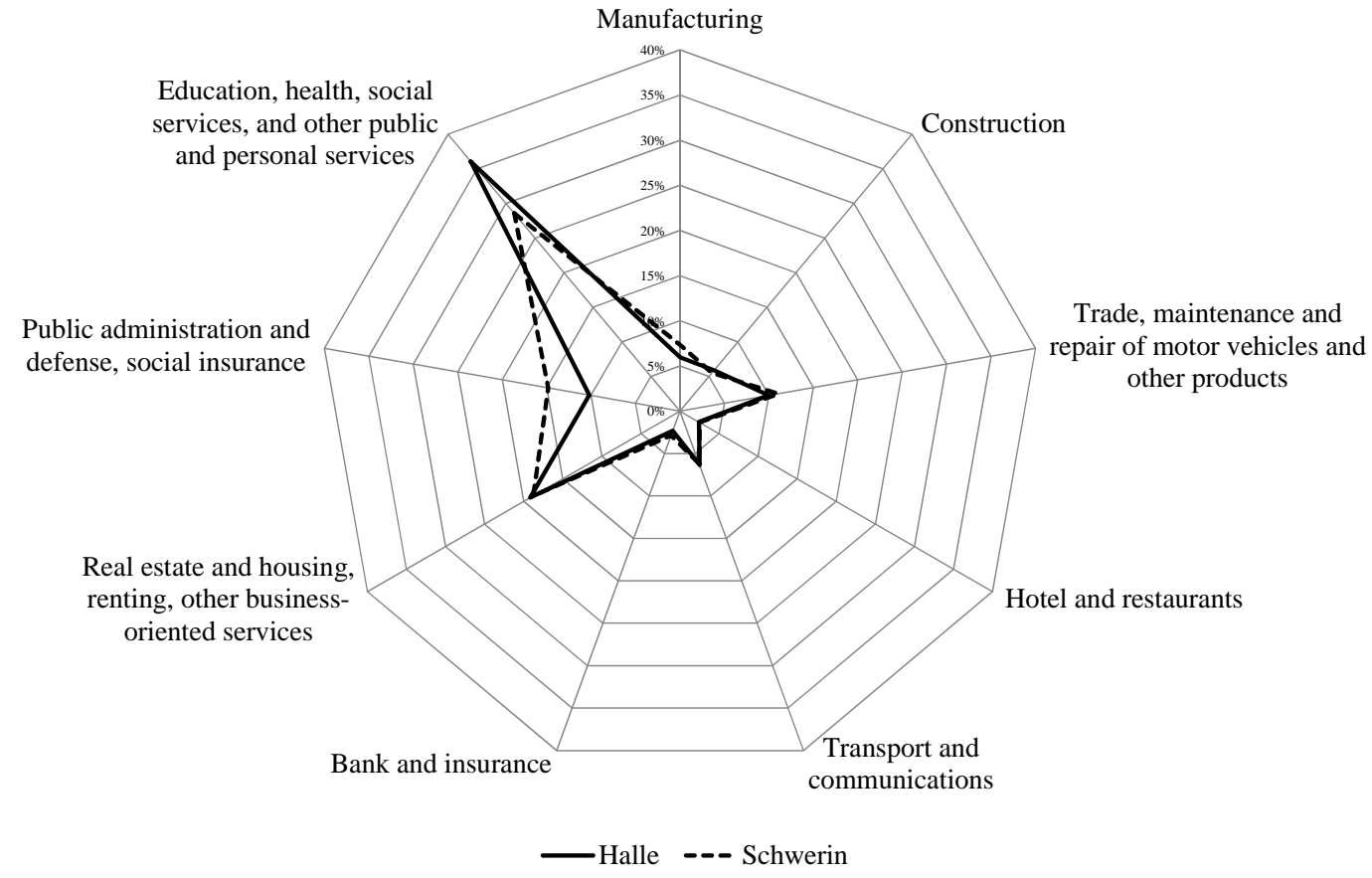

Source: Table A3 in annex.

Figure 9: Comparison of Employment Structure between Halle and Cottbus (2007)

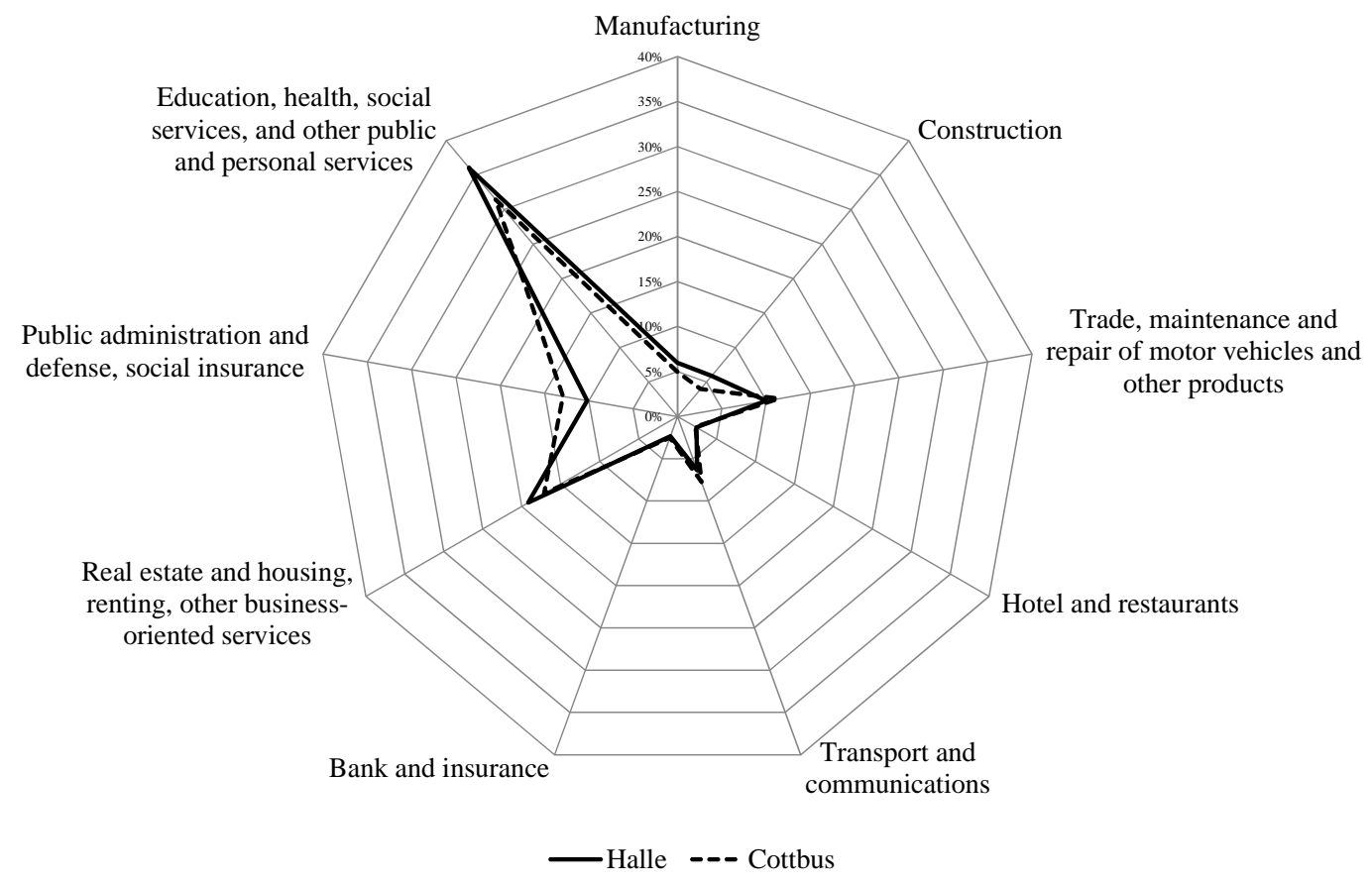

Source: Table A3 in annex. 
Figure 10: Comparison of Employment Structure between Halle and Essen (2007)

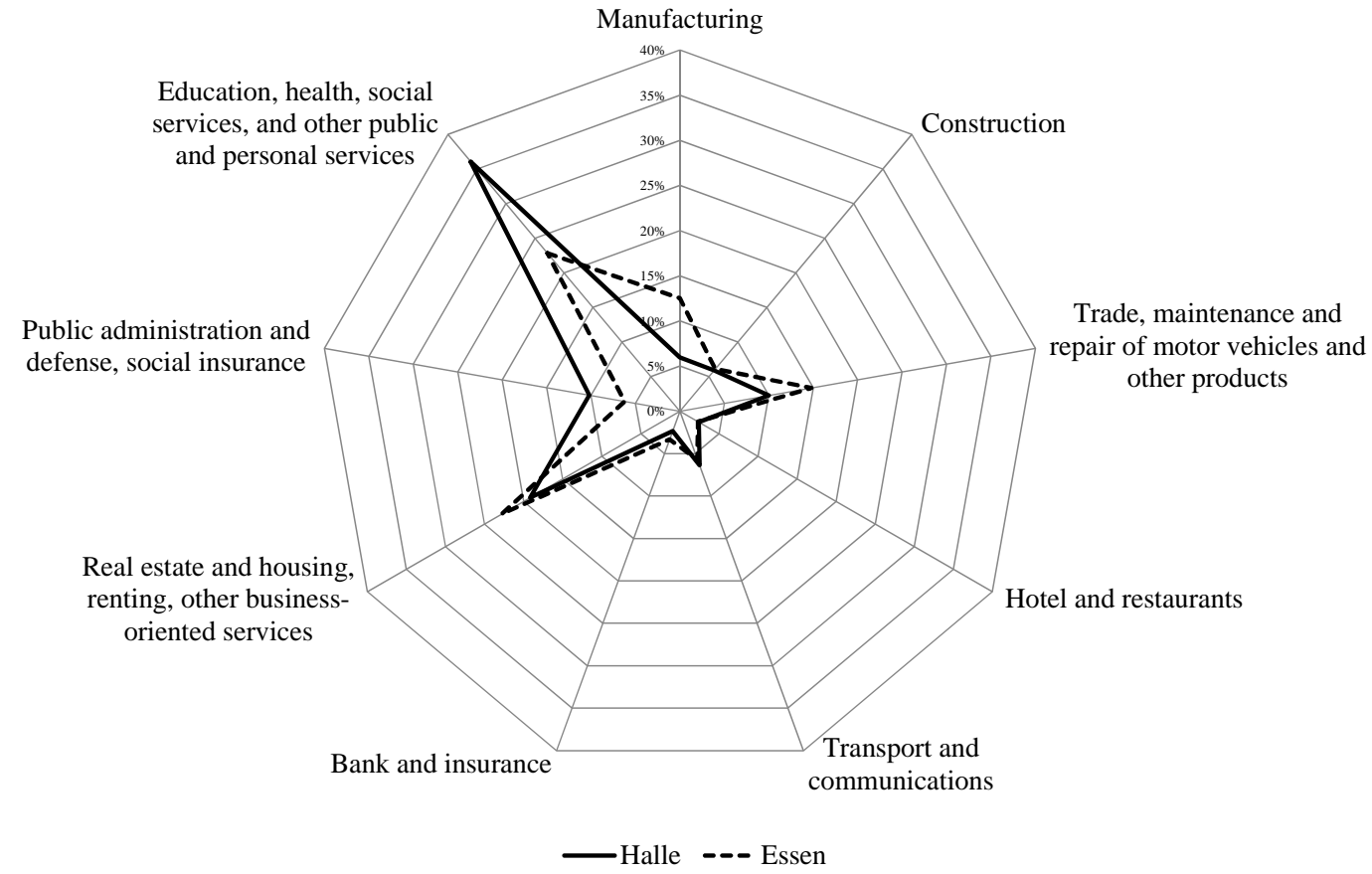

Source: Table A3 in annex.

Figure 11: Comparison of Employment Structure between Halle and Gelsenkirchen (2007)

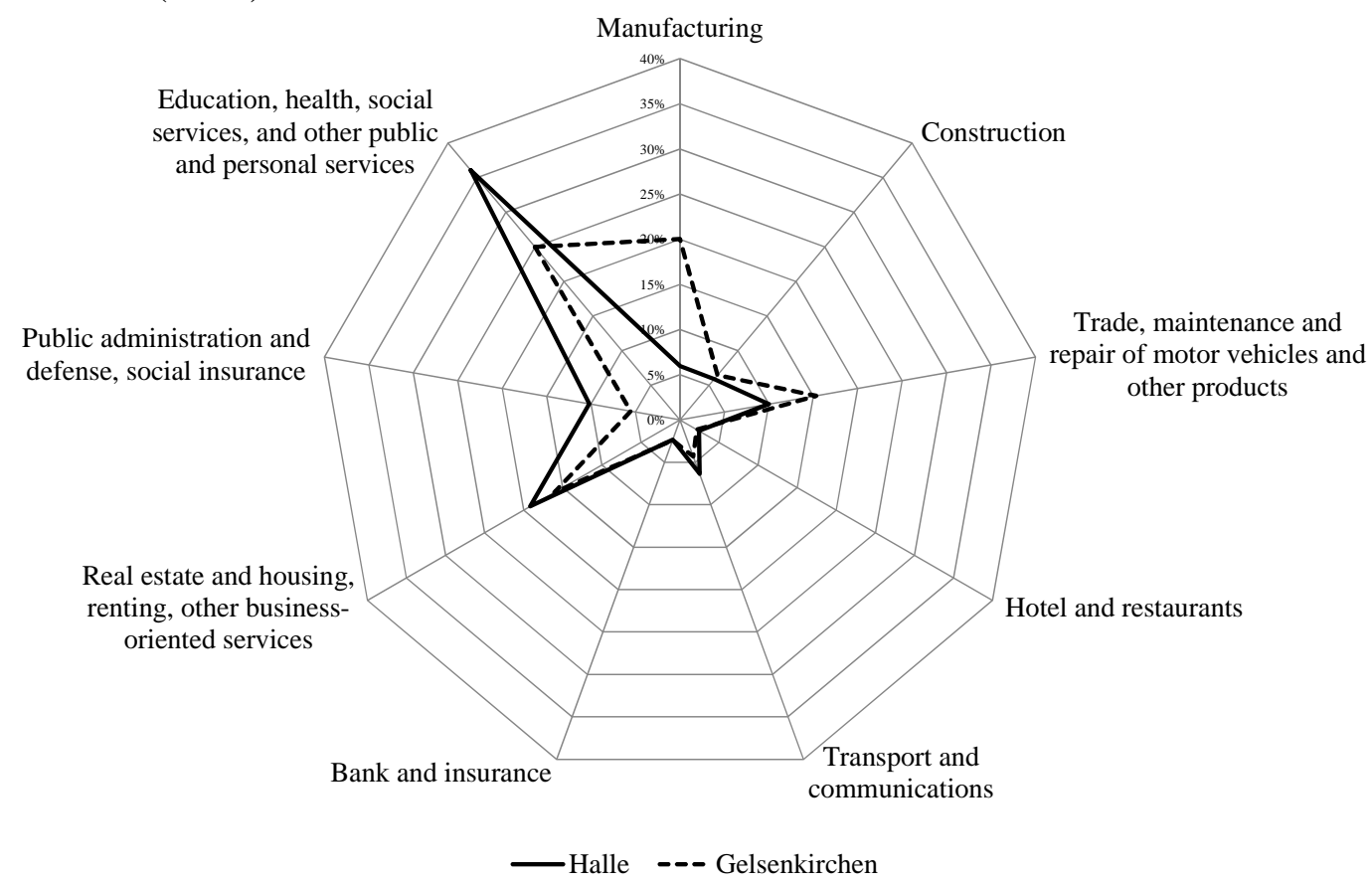

Source: Table A3 in annex. 
Figure 12: Comparison of Employment Structure between Halle and Dortmund (2007)

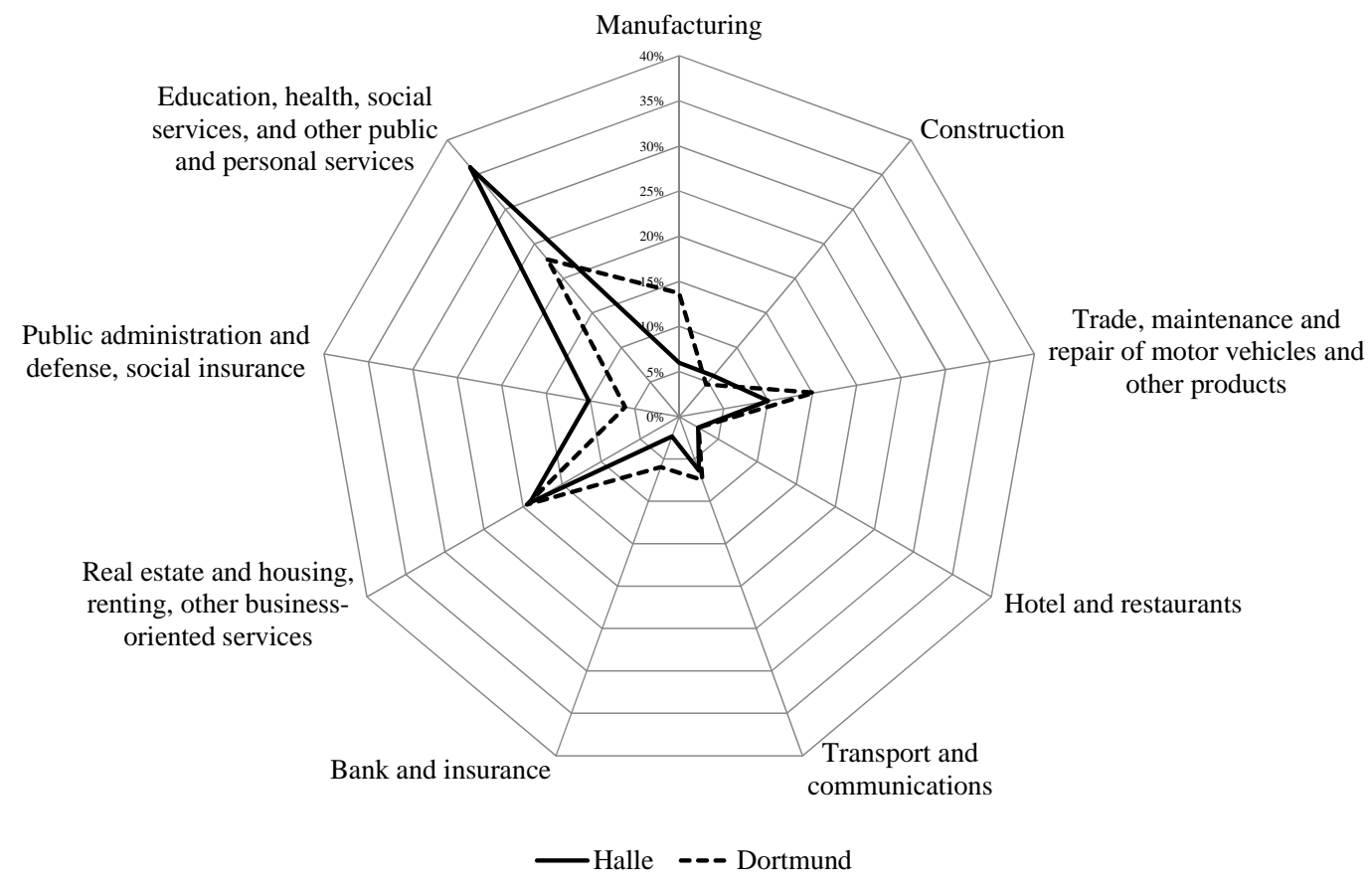

Source: Table A3 in annex.

\section{Some Political Responses to Urban Shrinkage in Eastern Germany}

\subsection{Popularity of Shrinkage-Oriented Policy}

"In response to the challenge of urban shrinkage, policymakers adopt growth-oriented and shrinkage-oriented approaches [see also Wiechmann and Pallagst, 2012)]. Most American cities have focussed on [the former strategies] such as growth management and smart growth, whereas more European cities have embraced [the latter policy option]” (Lin, 2014, p.185-186). Moreover, Hospers (2014) even argues that the best strategy for shrinking cities is to accept the shrinkage and to improve quality of life for the remaining residents. Most East German shrinking cities are no exception: instead of reforming the urban economic structure and stimulating growth, they have primarily tried to stop the negative demographic trends to overcome the ageing problems caused by shrinkage and are continuously searching for appropriate ways to maintain their population size. For this reason, most public promotion schemes in the former GDR have focused on the regeneration, redevelopment and revitalisation of city cores aimed at solving vacant housing problems, making historical centres more attractive and urban neighbourhoods greener, more compact and sustainable (Krautzberger, 2001; Herfert, 2002; Bullinger, 2002; Glock and Häußermann, 2004; Lötscher, 2005).

Table 2 shows the aims and financial resources of typical federal projects that have recently been initiated and implemented to support Germany’s shrinking cities (see 


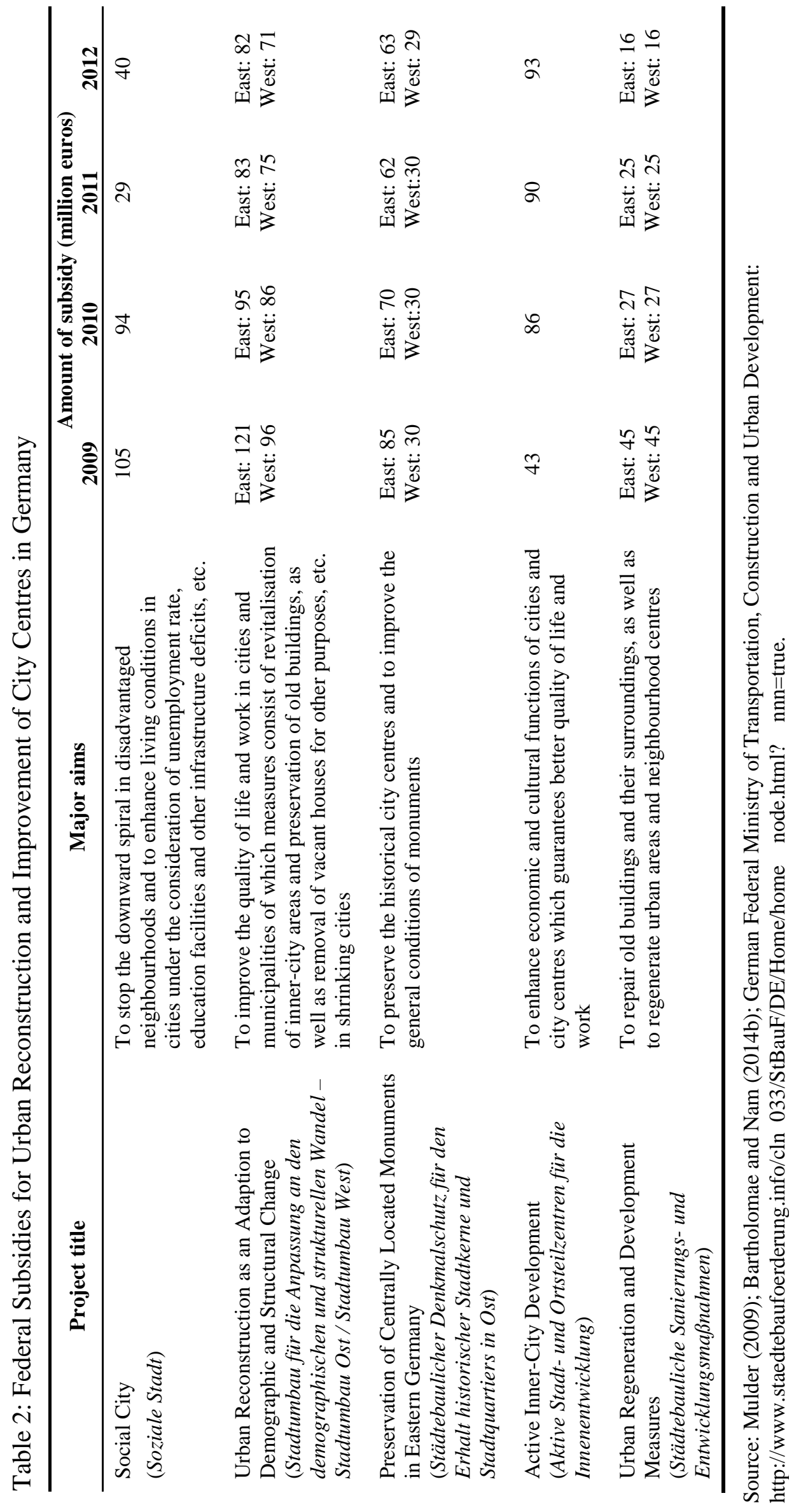




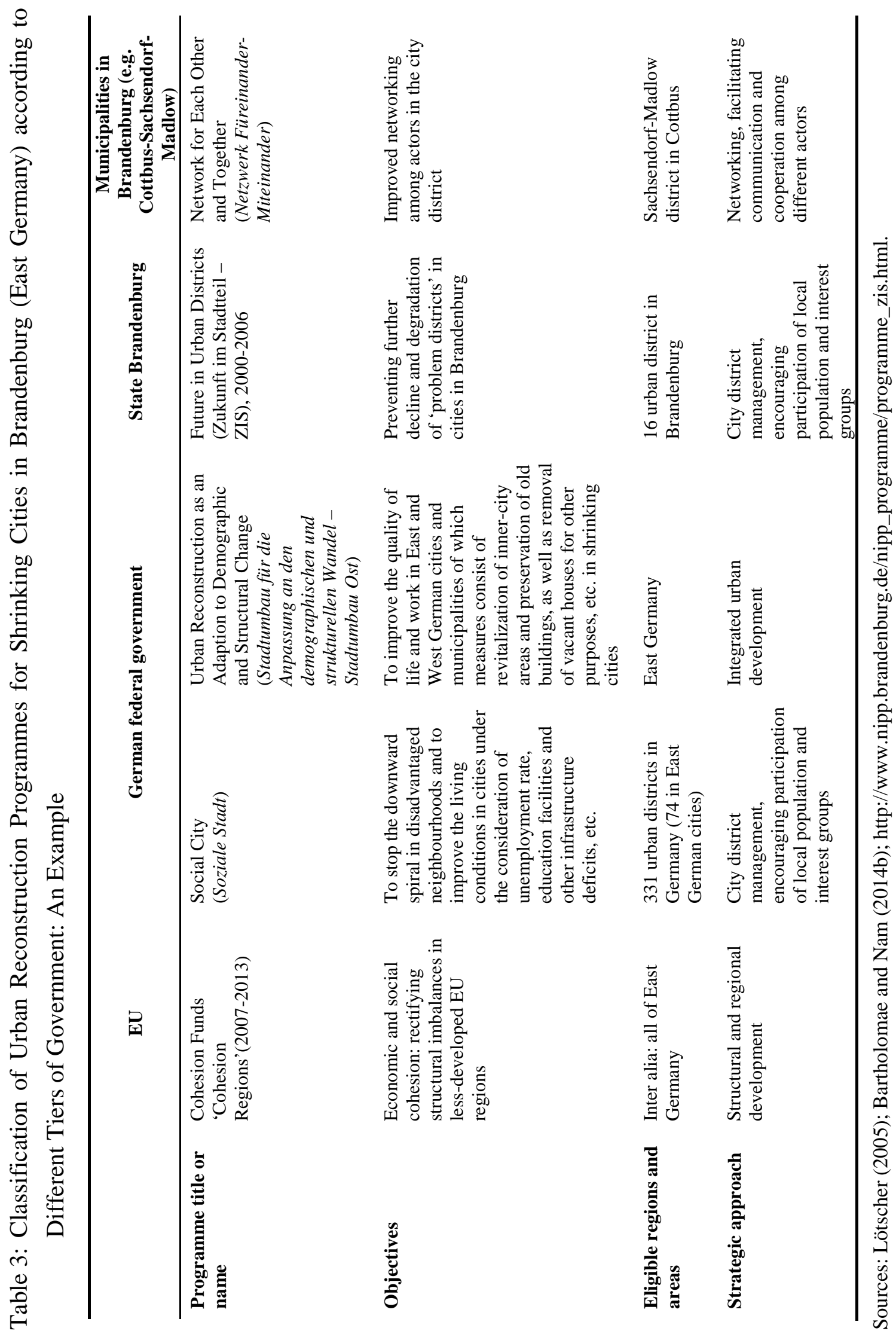


also Fuhrich and Kaltenbrunner, 2005). Taking the case of Cottbus in Brandenburg as an example, Table 3 offers an overview of the ways in which the urban rehabilitation programmes applied to the shrinking cities in eastern Germany are coordinated and financially promoted by the various tiers of government.

\subsection{Don't Die Slowly, Grow Smartly: A Superior Combating Strategy against Ur- ban Shrinkage}

The aforementioned cosmetic policy measures for urban regeneration do not appear to effectively solve the basic problems of the economic downturn in large East German cities, since their shrinkage is mainly attributed to the lack of a competitive manufacturing sector and its weak growth interdependence on modern business-oriented services. Repeatedly, Halle, for example, has expressed its desire to become a city specialised in modern research- and technology-oriented industrial activities in the fields of life science, new materials, solar energy, etc. However, innovation activities remain extremely weak in Halle, Cottbus and Schwerin (Berlemann and Jahn, 2013).

The successful structural changes in Dresden and Jena, as well as the smart growth of several Ruhr cities in recent years, deliver some policy lessons for those East German shrinking cities such as Halle, Cottbus and Schwerin. More specifically, would the economic emergence of Dresden have been possible without the establishment of a strong industrial and modern service sector? Can the smart economic growth of the Ruhr cities be solely attributed to the inner-city regeneration policy? What would have happened to them now if they had not patiently made intensive efforts for a long time to gradually restructure their economy?

Taking all of these aspects into consideration, continuously reforming the economic and industrial structure in Halle, Cottbus and Schwerin would seem to be a superior and more effective strategy, although it would be extremely challenging and costly. Such a policy orientation would tackle the key problems of their shrinkage more efficiently. In addition, those cities with an industrial tradition have also been playing an important role as central places: as already mentioned above, Halle, for example, is presently the fifth largest city in the eastern part of Germany and the largest city in Saxony-Anhalt, whereas Schwerin is the state capital of Mecklenburg-Western Pomerania. Therefore, it seems to be less desirable that these large cities eventually disappear.

To stop demographic shrinkage and achieve the smart growth of these cities in the long run, a more active industrial policy urgently needs to be implemented, which is designed not only based on the subsidiarity principle and own initiatives of these shrinking 
cities, but also considers the $\mathrm{SWOT}^{8}$ of specific urban economic structure, location quality including 'hard and soft' infrastructure endowment, etc. Such active growth-oriented policy measures should primarily target the development of a healthy local manufacturing cluster and the creation of a substantial number of high-tech small and medium-sized enterprises (SMEs) by fostering their innovation activities, which will attract other modern service firms into these cities.

More immediately these active policy measures should include, for example:

- The creation of technology parks, to better utilise existing social capital and exploit local industrial know-hows, as well as to attract innovative SMEs and entrepreneurs.

- The promotion of innovation potentials of city and local firms' research and development activities via the (1) creation of urban cluster among modern industries and business services; (2) establishment of regional innovation network with universities and research institutes; and (3) integration of such local networks into national and international ones.

- If urban path dependence creates lock-in effects, impedes the absorption capacity of new business ideas and technologies, and disturbs economic restructuring, a courageous political step needs to be taken to exit from such an industrial tradition.

- Exploring possibilities of attracting large (international) firms in terms of direct and indirect subsidies (see the case of Siemens in Dresden).

- Closer inter-city cooperation (e.g. between Halle and Leipzig) in terms of e.g. common regional marketing and local land-use policy in order to attract investment by other firms and to realise the economies of scale and scope.

- Continuous efforts towards urban revival aimed at not only slowing the demographic downturn of shrinking cities, but also, more effectively, at creating favourable working space and enhancing touristic attraction of city centre.

To a certain extent, all these measures can be combined with the existing urban revival promotion schemes, as shown in Table 2 and Table 3, as well as the traditional Joint Task for Improving Regional Economic Structure (Gemeinschaftsaufgabe Verbesserung der regionalen Wirtschaftsstruktur) - see also Bade and Eickelpasch (2011). Yet bettertargeted structural policy efforts and some special financial support programmes seem to be additionally required in order to rescue the shrinking cities in eastern Germany within a shorter period of time.

8 SWOT = strengths, weaknesses, opportunities and threats. 


\section{Conclusion}

In this study, those cities that are facing population losses and additionally undergoing economic transformation with clear symptoms of a structural crisis are defined as the shrinking cities. For the purpose of identifying such German shrinking cities, the population data and the real GVA data on the city level for the period between 1995 and 2007 are adopted. First of all, we question the widely applied parallelism of demographic and economic development to characterise urban shrinkage and highlight the fact that the usage of population change as a single indicator tends to lead not only to incorrect classification of the shrinking cities, but also to inappropriate policy design and implementation, which is aimed at combating urban shrinkage.

The lessons to be learnt from several Ruhr cities such as Essen, Gelsenkirchen and Dortmund and East German cities like Erfurt, Rostock and Magdeburg, suggest that urban economic growth can also be achieved based on the substantial presence of modern industries and business services, although population size declines gradually. In other words, these cities have successfully carried out structural transformation and achieved smart economic growth.

Furthermore, it should be strongly emphasised that the serious shrinkage of the East German cities investigated like Berlin, Halle, Cottbus and Schwerin is primarily caused by the failure of the post-industrial transformation process, and is primarily a structural problem. For this reason, current policy-based efforts to slow the downsizing process of the population in terms of urban regeneration measures can hardly solve the major problem of these cities in the long run. With a view to stopping the shrinkage and achieving smart growth, a more active industrial policy is suggested, which is designed based on the individual needs and initiatives of these shrinking cities, and also takes into consideration their specific urban economic structure, location quality, etc. More immediately, such active growth-oriented policy measures should ideally be adopted to develop a healthy local manufacturing cluster, to create a substantial number of high-tech SMEs and their innovation activities, and to attract modern business services in order to generate further synergy effects. 


\section{References}

Audirac, I. (2014), Shrinking Cities in Latin America, in: Richardson, H.W. and C.W. Nam (eds.), Shrinking Cities: A Global Perspective, Abingdon: Routledge, 28-46.

Bade, F.J. and A. Eickelpasch (2011), Fördermittel für strukturschwäche Gebiete: Die erfolgreiche 26-Milliarden-Euro-Subvention, DIW Wochenbericht 5/2011, 2-9.

Bartholomae, F. and C.W. Nam (2014a), Are Large Germany Cities Really Shrinking? Demographic and Economic Development in Recent Years, in: Richardson, H.W. and C.W. Nam (eds.), Shrinking Cities: A Global Perspective, Abingdon: Routledge, 86-104.

Bartholomae, F. and C.W. Nam (2014b), Halle: A Shrinking City in Eastern Germany, in: Richardson, H.W. and C.W. Nam (eds.), Shrinking Cities: A Global Perspective, Abingdon: Routledge, 255-263.

Berlemann, M. and J. E. Wesselhöft (2012), Total Factor Productivity in German Regions, CESifo Forum 13(2), 58-65.

Berlemann, M. and V. Jahn (2013), Relative Innovative Capacity of German Regions: Is East Germany Still Lagging Behind?, CESifo Forum 14(4), 42-50.

Bontje, M. and S. Musterd (2012), Understanding Shrinkage in European Regions, Built Environment 38, 153-161.

Bullinger, D. (2002), Schrumpfende Städte und leere Wohnungen: ein neues Phänomen und der Trend der Zukunft nicht nur in Ostdeutschland, Raumforschung und Raumordnung 60, 264-271.

Cheshire, P. and D. Hay (1989), Urban Problems in Western Europe, London: Unwin Hyman.

City of Halle (2010), Facts about the Halle (Saale) Business Location.

Cox, W. (2014), International Shrinking Cities, in: Richardson, H.W. and C.W. Nam (eds.), Shrinking Cities: A Global Perspective, Abingdon: Routledge, 11-27.

Cunningham-Sabot, E and S. Fol (2009), Shrinking Cities in France and Great Britain: A Silent Process?, in: Pallagst, K. et al. (eds.), The Future of Shrinking Cities - Problems, Patterns and Strategies of Urban Transformation in a Global Context, Berkeley, CA: University of California at Berkeley, 24-35.

Dormhardt, H. J. and G. Troeger-Weiß (2009), Germany’s Shrinkage on a Small Town Scale, in: Institute of Urban and Regional Development (IURD), The Future of Shrinking Cities: Problems, Patterns and Strategies of Urban Transformation in a 
Global Context, Monograph 2009-1, University of California, Berkeley, http://metrostudies.berkeley.edu/shrinking.html, 161-168.

Franz, P. (2004), Shrinking Cities - Shrinking Economy? The Case of East Germany, http://www.difu.de/node/6055.

Friedrich, P. and C.W. Nam (2013), Innovation-oriented Land-use Policy at the Subnational Level: Case Study from Germany, Studies in Regional Science 43, 223-240.

Friedrichs, J., H. Häußermann and W. Siebel (eds. 1986), Süd-Nord-Gefälle in der Bundesrepublik? Sozialwissenschaftliche Analysen, Opladen: Westdeutscher Verlag.

Fuhrich, M. (2003), Stadt retour Dimensionen und Visionen der schlanken Stadt, Information zur Raumentwicklung 10(11), 589-604.

Fuhrich, M. and R. Kaltenbrunner (2005), Der Osten - jetzt auch im Westen? Stadtumbau-West und Stadtumbau-Ost - zwei ungleich Geschwister, Berliner Debatte Initial 16(6), 41-54.

Gatzweiler, P., K. Meyer and A. Milbert (2003), Schrumpfende Städte in Deutschland? Fakten und Trends, Informationen zur Raumentwicklung 10(11), 557-574.

Gatzweiler, P. and A. Milbert (2009), Schrumpfende Städte wachsen und wachsende Städte schrumpfen, Information zur Raumentwicklung 16(7), 443-455.

Glaeser, E. L., H. D. Kallal, A. Scheinkman and A. Schleifer (1992), Growth in Cities, Journal of Political Economy 100, 1226-1252.

Glock, B. and H. Häußermann (2004), New Trends in Urban Development and Public Policy in Eastern Germany: Dealing with the Vacant Housing Problem on the Local Level, International Journal of Urban and Regional Research 28(4), 919-930.

Göschel, A. (2003), Schrumpfende Städte: Planerische Reaktionen auf den Leerstand, http://alt.irs-net.de/download/RG17_Goeschel.pdf.

Hannemann, C. (2003), Schrumpfende Städte in Ostdeutschland - Ursachen und Folgen einer Stadtentwicklung ohne Wirtschaftswachstum, Aus Politik und Zeitgeschichte, Beiträge zur Wochenzeitung Das Parlament B(28), 16-25.

Herfert, G. (2002), Disurbanisierung und Reurbanisierung - Polarisierte Raumentwicklung in der ostdeutschen Schrumpfungslandschaft, Raumforschung und Raumordnung 60, 334-344.

Hollander, J. B., K. Pallagst, T. Schwarz and F. J. Popper (2009), Planning Shrinking Cities, http://policy.rutgers.edu/faculty/popper/ShrinkingCities.pdf.

Hospers, G.J. (2014), Urban Shrinkage in the EU, in: Richardson, H.W. and C.W. Nam (eds.), Shrinking Cities: A Global Perspective, Abingdon: Routledge, 48-58. 
Krautzberger, M. (2001), Wohnungsleerstand und Rückbau: die ostdeutsche Stadtentwicklung, Raum 44, 40-43.

Kermer, S. (2007), Verstädterung, Migration und wirtschaftliche Entwicklung, Berlin: LIT Verlag.

Lang, T. and E. Tenz (2003), Von der schrumpfenden Stadt zur Lean City, Dortmund: Dortmunder Vertrieb für Bau- und Planungsliteratur.

Leadbeater, D. (2009), Single-industry Resource Communities, “Shrinking”, and the New Crisis of Hinterland Economic Development, in: Institute of Urban and Regional Development (IURD), The Future of Shrinking Cities: Problems, Patterns and Strategies of Urban Transformation in a Global Context, Monograph 2009-1, University of California, Berkeley, http://metrostudies.berkeley.edu/shrinking.html, 89-100.

Lin, M.C.Y. (2014), Are Cities in Taiwan Shrinking?, in: Richardson, H.W. and C.W. Nam (eds.), Shrinking Cities: A Global Perspective, Abingdon: Routledge, 182-201.

Lötscher, L. (2005), Shrinking East German Cities?, Geographia Polonica 78/1, 79-98. Malthus, T.R. (1798), An Essay on the Principle of Population, London: J. Johnson.

Martinez-Fernandez, C., I. Audirac, S. Fol and E. Cunningham-Sabot (2012), Shrinking Cities: Urban Challenges of Globalization, International Journal of Urban and Regional Research 36, 213-225.

Mills, E. S. and F. McDonald (1992), Sources of Metropolitan Growth, Center for Urban Policy Research of the Rutgers University, New Brunswick (New Jersey).

Morrill, R. (2014), Shrinking Cities: United States, in: Richardson, H.W. and C.W. Nam (eds.), Shrinking Cities: A Global Perspective, Abingdon: Routledge, 61-73.

Mulder, A. (2009), Shrinking Cities: Explaining (Local) Government Response, http://newurbanquestion.ifou.org/proceedings/8\%20New\%20Approaches\%20of\%20 Urban\%20Governance/full\%20papers/F023_Mulder_Andre_Shrinking\%20Cities.pdf.

Nam, C.W., R. Parsche and A. Gebauer (2005), Regional Technology Policy and Factors Shaping Local Innovation Networks in Small German Cities, European Planning Studies 13, 661-683

Nipper, J., K. Schulz and E. Wiratanaya (2009), Germany's Demographic Changes and Its Implications for Shrinking Cities: Disaster or Development Opportunities, Paper presented at the conference on The Evolution of Integration in Europe, 20 Years after the fall of the Berlin Wall, Allendorf, 11-14 October, http://www.wlu.ca/viessmann/Integration/Nipper_Schulz_Wiratanaya.pdf. 
Oswalt, P. (2006), Shrinking Cities, Vol. 1 International Research, Ostfildern-Ruit: Hatje Cantz Verlag.

Pike, A., A. Rodriguez-Pose and J. Tomaney (2007), What Kind of Local and Regional Development and for Whom?, Regional. Studies 41, 1253-1269.

Ragnitz, J., G. Müller and A. Wölfl (2001), Produktivitätsunterschiede und Konvergenz von Wirtschaftsräumen - Das Beispiel der neuen Länder, IHW-Sonderheft 2011-3, Halle.

Raschke, W. and A. Schultz (2006), Stadtbevölkerung im Wandel - Die Bevölkerungsentwicklung und-struktur von Halle, in: Friedrich, K. and M. Frühauf (eds.), Halle und sein Umfeld, Halle: Mitteldeutscher Verlag, 50-56.

Richardson, H and C.W. Nam (2014), Shrinking Cities, in: Richardson, H.W. and C.W. Nam (eds.), Shrinking Cities: A Global Perspective, Abingdon: Routledge, 1-7.

Rink, D., A. Haase, M. Bernt, T. Arndt and J. Ludwig (2010), Urban Shrinkage in Leipzig and Halle, the Leipzig-Halle Urban Region, Germany, Leipzig: Helmholtz Centre for Environmental Research.

Rink, D., P. Rumpel, O. Slach, C. Cortese, A. Violante, P. Calza Bini, A. Haase, V. Mykhnenko, B. Nadolu, C. Couch, M. Cocks and R. Krzystofik (2012), Governance of Shrinkage: Lessons Learnt from Analysis for Urban Planning and Policy, Leipzig: Helmholtz Centre for Environmental Research.

Schlömer, C. (2009), Demographic Change in Germany from a Spatial Point of View: Beyond East vs. West, Paper presented at the conference on The Evolution of Integration in Europe, 20 Years after the fall of the Berlin Wall, Allendorf, 11-14 October, http://www.wlu.ca/viessmann/Integration/Schlomer.pdf.

Stadt Halle (2008), Integriertes Stadtentwicklungskonzept: Gesamtstädtische Entwicklungstendenzen und Halle (Saale), http://www.halle.de/VeroeffentlichungenBinaries/265/117/br_isek_teil1endfassung_ 2008.pdf

Statistisches Bundesamt (2000), Bevölkerungsentwicklung Deutschlands bis 2050, Ergebnisse der 9. koordinierten Bevölkerungsvorausrechnung des Bundes und der Länder, Wiesbaden.

Steinführer, A. and A. Haase (2007), Demographic Change as a Future Challenge for Cities in East Central Europe, Geografiska Annaler 89B, 183-195.

Szirmai, A. (2005), Socio-Economic Development, Cambridge: Cambridge University Press. 
Tiebout, C. (1956), A Pure Theory of Local Expenditures, Journal of Political Economy 64, 416-424.

Turok, I. and V. Mykhnenko (2007), The Trajectories of European Cities 1960-2005, International Journal of Urban Policy and Planning 24, 165-182.

United Nations (UN, 2014): World Urbanization Prospects - 2014 Revision, United Nations: New York.

Wallosek, W. (2006), Am Anfang standen Salz und Kohle - Etappen der wirtschaftlichen Entwicklung des engeren helleschen Raumes, in: Friedrich, K. and M. Frühauf (eds.), Halle und sein Umfeld, Halle: Mitteldeutscher Verlag, 42-49.

Wiechmann, T. (2009), What Are the Problems of Shrinking Cities? Lessons Learned from an International Comparison, in: Institute of Urban and Regional Development (IURD), The Future of Shrinking Cities: Problems, Patterns and Strategies of Urban Transformation in a Global Context, Monograph 2009-1, University of California, Berkeley, http://metrostudies.berkeley.edu/pubs/proceedings/Shrinking/4Wiechmann_PA_final. pdf.

Wiechmann, T. and K.M. Pallagst (2012), Urban Shrinkage in Germany and the USA: A Comparison of Transformation Patterns and Local Strategies, International Journal of Urban and Regional Research 36, 261-280.

Wiegandt, C.C. (2000), Urban Development in Germany - Perspectives for Future, GeoJournal 50, 51-55. 


\section{Annex}

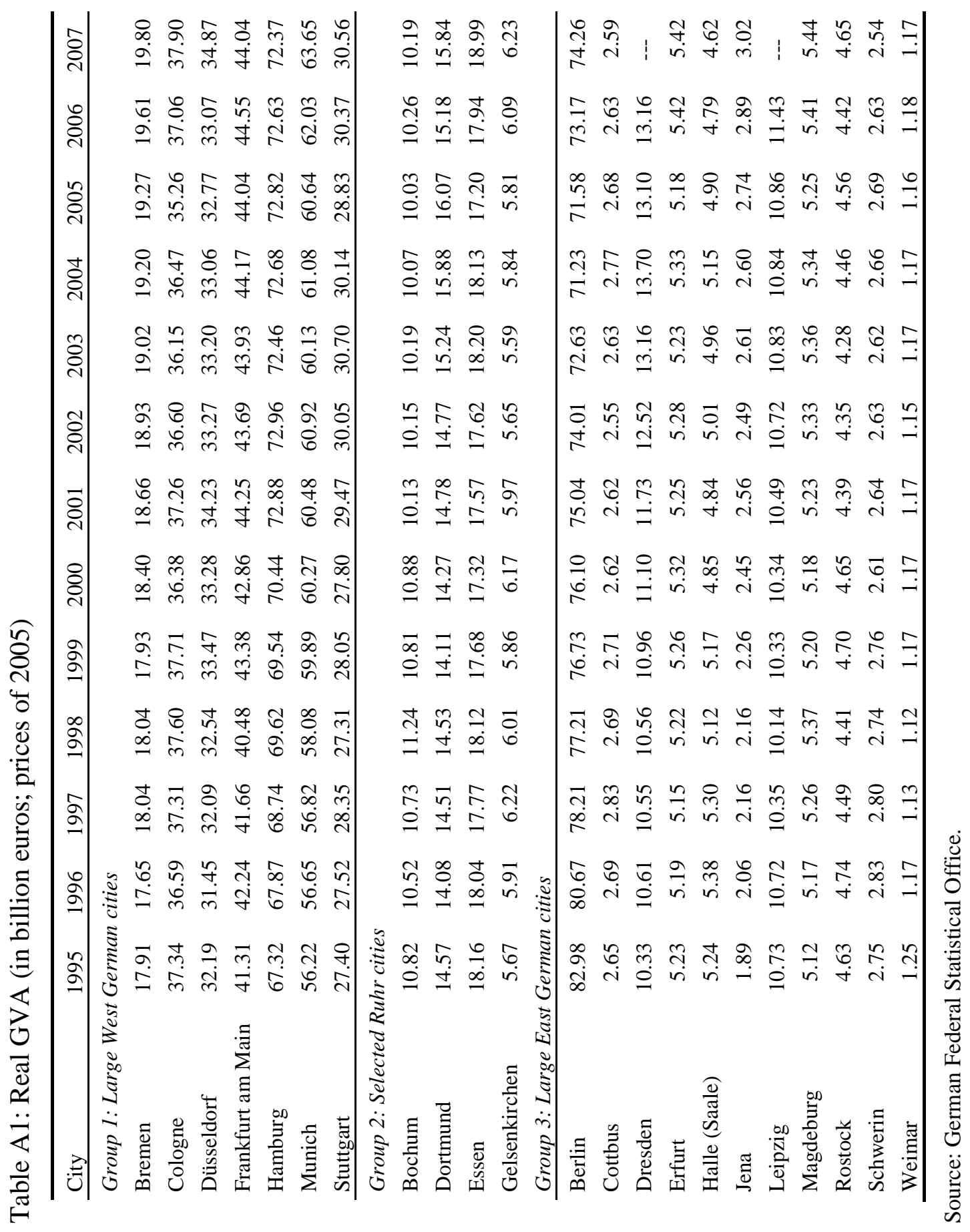




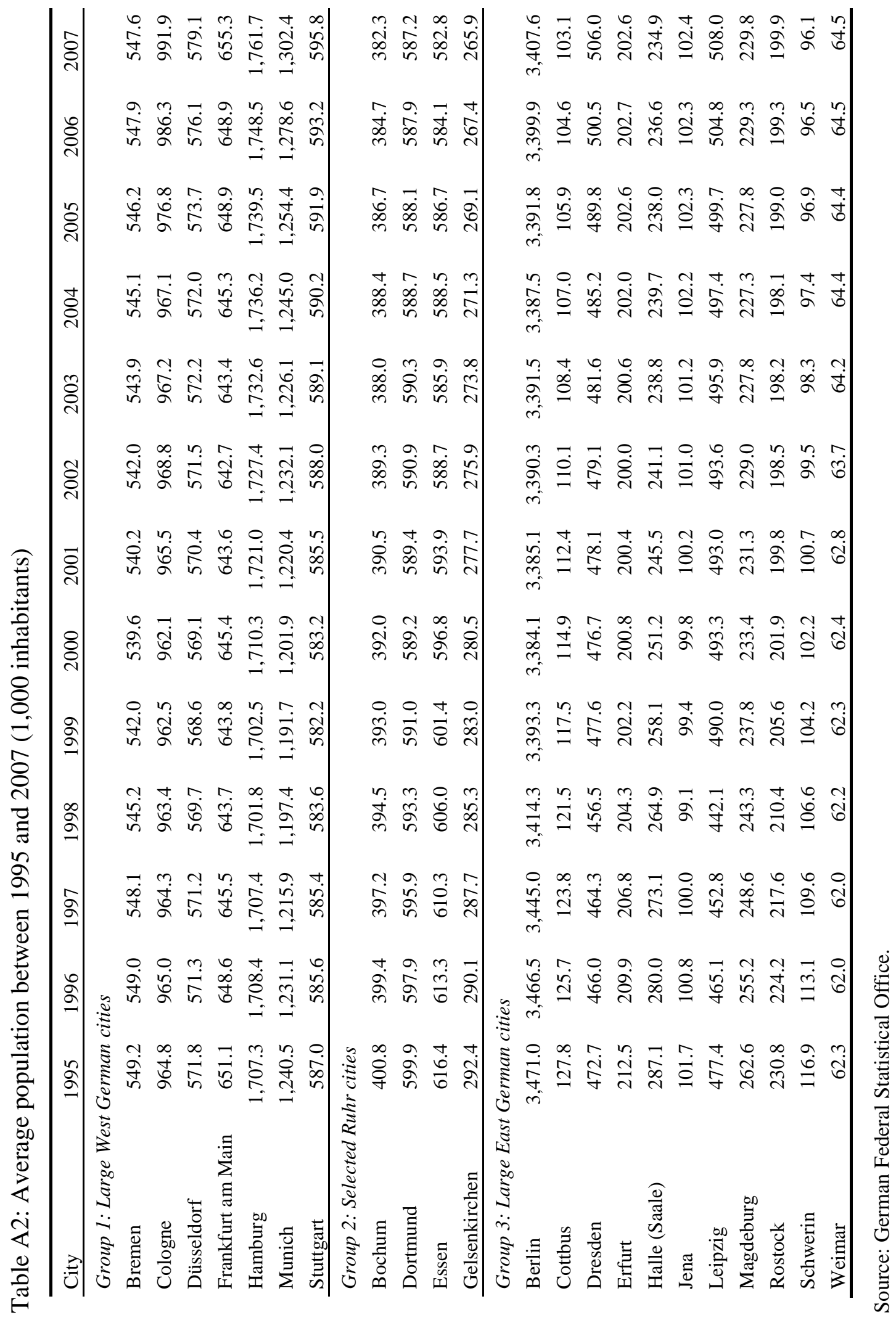




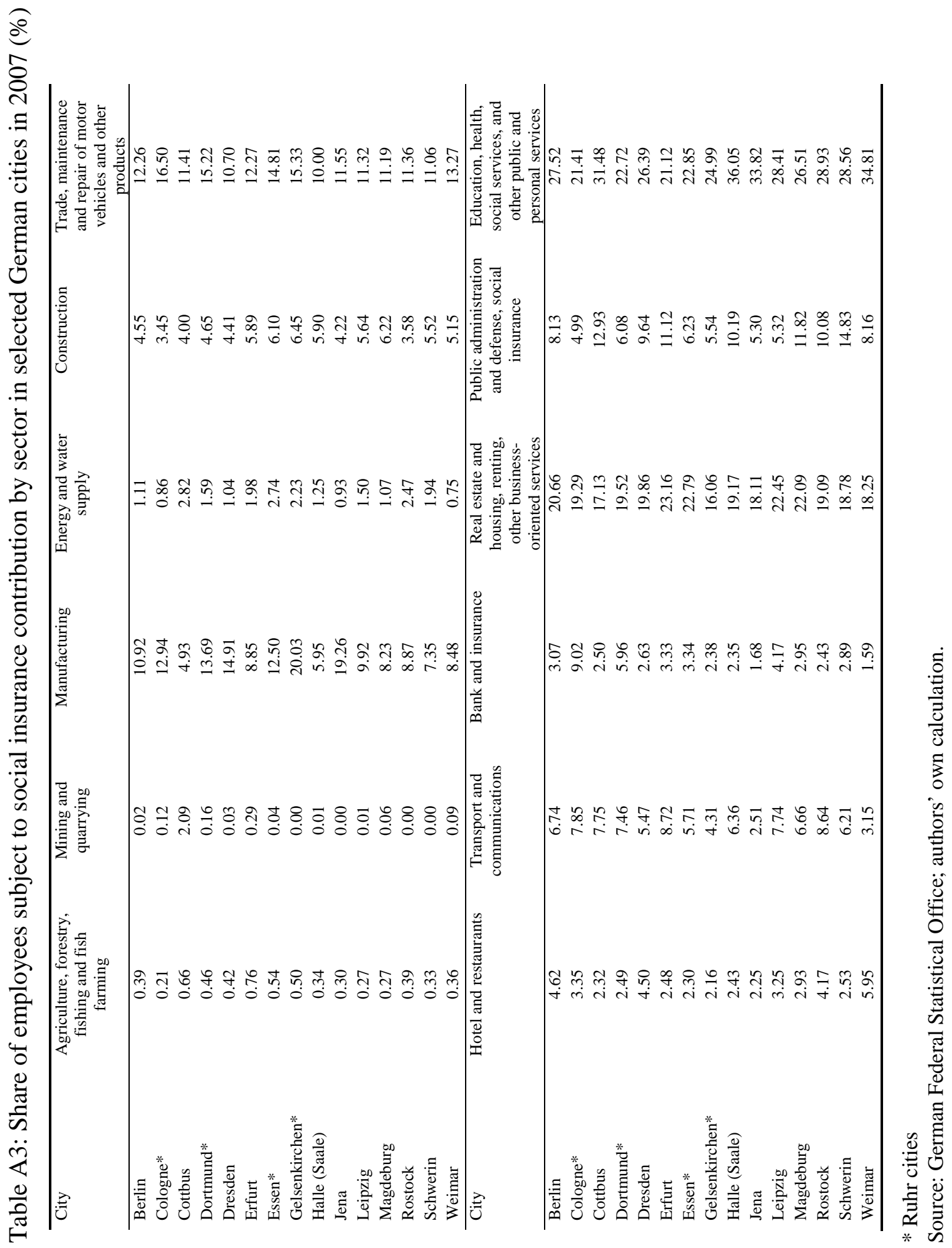

